\title{
An Integrated View of Precambrian Eumetazoan Evolution
}

\author{
E.H. DAVIDSON ${ }^{1}$ AND D.H. ERWIN ${ }^{2}$ \\ ${ }^{1}$ Division of Biology 156-29, California Institute of Technology, Pasasdena, California 91125; \\ ${ }^{2}$ Department of Paleobiology, MRC-121, Smithsonian Institution, Washington, D.C. 20013-7012, \\ and Santa Fe Institute, Santa Fe, New Mexico, 87501 \\ Correspondence: davidson@caltech.edu
}

\begin{abstract}
The eumetazoan clade of modern animals includes cnidarians, acoels, deuterostomes, and protostomes. Stem group eumetazoans evolved in the late Neoproterozoic, possibly before the Marinoan glaciation, according to a variety of different kinds of evidence. Here, we combine this evidence, including paleontological observations, results from molecular and morphological phylogeny, and paleoecological considerations, with deductions from the organization of the gene regulatory networks that underlie development of the bilaterian body plan. Eumetazoan body parts are morphologically complex in detail, and modern knowledge of gene regulatory network structure shows that the control circuitry required for their development is hierarchical and multilayered. Among the consequences is that the kernels of the networks that control the early allocation of spatial developmental fate canalize the possibilities of downstream evolutionary change, a mechanism that can account for the appearance of distinct clades in early animal evolution. We reconstruct preeumetazoan network organization and consider the process by which the eumetazoan regulatory apparatus might have been assembled. A strong conclusion is that the evolutionary process generating the genomic programs responsible for developmental formulation of basic eumetazoan body plans was in many ways very different from the evolutionary changes that can be observed at the species level in modern animals.
\end{abstract}

The appearance of the Eumetazoa represents a significant evolutionary transition in the history of life. Most eumetazoans, or their ancestors, exhibit some form of bilaterial symmetry, an innovation often thought to be associated with the regionalization of sensory structures and the eventual elaboration of a central nervous system. In this chapter, we integrate data on the origin and early evolution of eumetazoans as observed in the fossil record and phylogenetic information on the relationships of major metazoan clades, with insights deriving from the gene regulatory networks (GRNs) that underlie the developmental process. Recent knowledge of GRN structure and function provides a primary focus on mechanisms of assembly and change of the genomic programs that control the developmental construction of eumetazoan body plans.

A robust phylogeny is crucial to our discussion, and as we discuss further below, the phylogenetic relationships between the principal clades of the cnidarians, acoels, and nematodermatids, and the protostomes plus deuterostomes, are now well established, and they provide this fundamental framework. However, the phylogenetic placement of several groups remains highly controversial, including the issue of whether sponges represent a single clade, or are paraphyletic, the affinities of the placazoan Trichoplax and the phylogenetic placement of the ctenophores (Fig. 1). The current level of controversy regarding the phylogenetic relationships of these basal metazoan groups indicates that it is premature to address developmental evolutionary processes at that level. Resolution of these phylogenetic issues is essential for determining characters present in the last common ancestor at various nodes along the more basal metazoan evolutionary tree, but they are not vital to eumetazoan evolution per se.
The fossil record provides important constraints on metazoan evolution in general. The earliest current record of metazoans comes from molecular fossils, biomarkers, preserved in rocks older than 635 million years ago (mya) in Oman. Early to Middle Ediacaran rocks of the Doushantuo Formation in southern China preserve a rich assemblage of algae and microfossils and an array of exquisitely preserved metazoan embryos. Several of these are most plausibly interpreted as representing bilaterian metazoan clades. The most obvious component of the fossil record of the Ediacaran Period (635-542 mya) are the assemblages of the soft-bodied Ediacaran macrofauna dating to 579-542 mya. Although many of these exhibit apparent bilaterial symmetry, only one of them, Kimberella (555 mya; White Sea, Russia), can reasonably be considered as representing a protostome; no deuterostomes are known. By the end of the Early Cambrian, 530 mya, a diverse assemblage of bilaterian clades is well established in the fossil record, including virtually every major metazoan clade, from arthropods to vertebrates. This has given rise to the popular concept of the "Cambrian explosion."

A better understanding of the developmental evolutionary events that occurred during the late Neoproterozoic ( 750-542 mya) is important not only for understanding the mechanisms associated with the construction of animal body plans, but also for improving interpretations of the fossil record. Developmental evidence suggests that the capacity to produce "bilaterian" morphological characters had evolved by the last common ancestor of cnidarians + other eumetazoans. Additional characters appeared with acoels and with protostomes + deuterostomes. Consequently, there is no unique association between the definitive suite of "bilaterian" characters and any single clade. Rather (and 


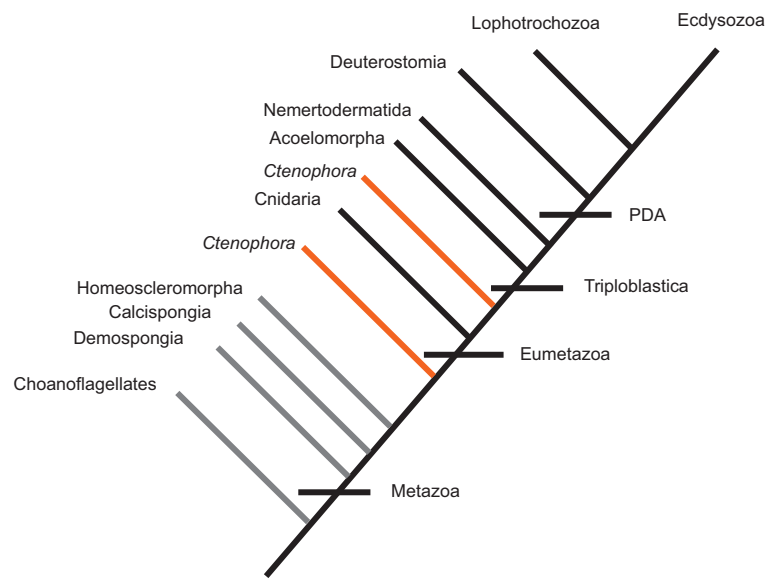

Figure 1. A consensus metazoan phylogeny, based on a variety of recent molecular studies as discussed in the text. The sponges are shown as three separate clades, consistent with several recent studies, and the Nemertodermatida are placed between the acoels and the protostome-deuterostome ancestor (PDA), as suggested by several recent studies discussed in text. The position of several groups remains uncertain. Two alternative placements of the ctenophores are shown; the phylogenetic position of the placazoans (Trichoplax) is probably between the sponges and cnidarians, but recent studies have given conflicting results so they are not shown on this tree.

indeed, unsurprisingly), "bilaterian" characters appeared progressively through eumetazoan evolution. This stands in contrast to a number of papers interpreting the nature of an "urbilaterian" (Kimmel 1996; Arendt and Wittbrodt 2001; Balavoine and Adoutte 2003; Hejnol and Martindale 2008). Recognition of the sequential evolution of bilaterian characters sheds new light on interpretation of fossil evidence for "bilaterians."

We begin with a discussion of the phylogenetic framework for Metazoa and then proceed to the precambrian fossil record of eumetazoan evolution, before integrating the fossil and developmental patterns within a phylogenetic context. In the later part of the paper, we turn to the issue of how the developmental GRNs associated with eumetazoans may have arisen and sketch out the evolutionary steps that are indicated by existing evidence. Several recent papers have proposed morphological scenarios for the early evolution of animals (Martindale et al. 2002; Finnerty 2005; Baguña et al. 2008; Nielsen 2008; Martindale and Hejnol 2009). In contrast, we are interested here in the evolutionary changes in the structural character of developmental GRNs that may have underlayed eumetazoan evolution during the late Neoproterozoic and Cambrian, and the implications of these changes.

\section{METAZOAN PHYLOGENY AND MOLECULAR CLOCKS}

Metazoan phylogenies have used various combinations of morphological, developmental, and sequence data, the latter largely from $18 \mathrm{~S}$ rRNA and conserved protein sequence. During the past 5 years, these analyses have become far more robust, sampling a greater variety of taxa, adding more gene sequences and other information including secondary structures and the presence or absence of specific markers such as microRNAs (miRNAs). More sophisticated phylogenetic algorithms have been introduced as well, including methods for statistical testing between alternative phylogenetic models. Consequently, metazoan phylogeny is increasingly robust, although some critical areas of controversy still remain.

Virtually all recent analyses agree on a topology with choanoflagellates as the closest living relatives of metazoans, followed by sponges, cnidarians, and acoel flatworms, and finally the last common ancestor of lophotrochozoans + ecdysozoans (protostomes) and deuterostomes (Fig. 1) (Douzery et al. 2004; Nielsen 2008; Peterson et al. 2008; Minelli 2009). Nielsen (2008) recently summarized the discordance among various recent molecular-based phylogenies of the most basal metazoan groups. As described briefly below, there is little consensus. Because our emphasis here is on the early evolution of eumetazoans, phylogenetic relationships among the various lophotrochozoan, ecdysozoan, and deuterostome lineages need not concern us.

Several analyses of morphologic and molecular data for sponges suggest that they are polyphyletic, having arisen multiple times at the base of the metazoa (Peterson and Butterfield 2005; Sperling et al. 2007; Nielsen 2008), although this is disputed (Dunn et al. 2008; Philippe et al. 2009; Schierwater et al. 2009). Differences in taxon sampling appear to have been a major reason for these divergent results (Sperling et al. 2009a). The most recent analysis (Sperling et al. 2009b) uses seven nuclear genes from 29 sponges and a variety of eumetazoan outgroups. The results strongly support sponge paraphyly, and most importantly, the phylogenetic tests applied are strongly inconsistent with sponges as a single clade, or with the existence of a clade of diploblastic organisms (Porifera + Cnidaria + placazoa). A significant result of this study is that the homoscleromorph sponges appear to be the sister group to the eumetazoans. Homoscleromorphs are a small group of unusual sponges that possess several characters not found in other sponges, including a basement membrane with collagen IV, in both adults and larvae, and other details of cell structure (Nielsen 2008). Placazoa (Trichoplax) are likely to be basal to Eumetazoa (Srivastava et al. 2008; Sperling et al. 2009a), despite a contrary claim that they are basal instead to a clade of diploblasts (Schierwater et al. 2009). The position of the ctenophores is even more contentious and remains unresolved. Some studies favor them as the sister group to Cnidarians, and others as the sister to acoels + remaining bilaterian clades (summarized in Nielsen 2008). One recent study suggests that they are the most basal metazoan clade (Dunn et al. 2007), although this receives no support from other recent analyses. There is little known of the developmental molecular biology of ctenophores, and their phylogenetic position is not relevant for our discussion here. Several interesting recent papers suggest that the nermatodermatids lie above acoels and below the PDA (Wallberg et al. 2007; Baguña et al. 2008; Paps et al. 2009). As discussed further below, these groups may represent the surviving descendants of a once richer late Neoproterozoic group of early bilaterian clades. 
Because the fossil record only provides minimal estimates of the appearances of distinctive and fossilizable morphologies, molecular clock estimates in principle offer critical additional information on the timing of the diversification of eumetazoan lineages (Aris-Brosou and Yang 2003; Douzery et al. 2004; Peterson and Butterfield 2005; Peterson et al. 2008). Recent molecular clock results indicate divergences that are largely congruent with the fossil record, in contrast to earlier results that suggested divergences occuring much earlier in the Proterozoic. For example, two recent studies, by Douzery et al. (2004) and Peterson et al. (2008), respectively, report dates for the origin of the Metazoa near 850/770 mya, eumetazoa near 695/680 mya, and the protostome-deuterostome divergence near 640 mya (all with uncertainties of tens of millions of years). Thus, sponges and cnidarians appeared during the Cryogenian, with the protostome-deuterostome ancestor close to the base of the Ediacaran, and bilaterian divergences during the Ediacaran (for geologic framework and time units, see Fig. 2).

\section{THE FOSSIL RECORD OF BILATERIA}

\section{Environmental Effects}

The origin of Metazoa and of eumetazoans occurred during an interval of considerable environmental change. Two extensive glaciations, affecting much of the globe, occurred beginning $\sim 730$ mya and ended at 635 mya (Kaufman et al. 1997; Condon et al. 2005). These are known to geologists as the Sturtian and Marinoan glaciations, respectively, after the regions in which they were first identified. Each may have had several pulses of glaciation, but more importantly, persuasive geologic evidence suggests that ice extended close to the equator and may have resulted in an essentially global "snowball Earth," although refugia evidently persisted, because the origins of animals, algae, and fungi lie much deeper than these events (Hoffman et al. 1998; Hoffman and Schrag 2002). The duration of these glacial intervals is not yet well constrained, but they appear to have lasted for millions of years, and durations of tens of millions of years have been claimed. A later, probably less-extensive, glaciation occurred near 580 mya (the Gaskiers glaciation; Thompson and Bowring 2000), and there was possibly an additional glacial event close to the Ediacaran-Cambrian boundary at 542 mya.

Aerobic respiration provides about an order of magnitude more energy for the same amount of food than does anaerobic metabolism. Consequently, oxygen is critical to the origin and diversification of metabolically active, complex organisms, and oxygen concentrations limit the maximum size of organisms. Many paleontologists have argued that rapid increases in oxygen levels were associated with the initial diversification of animals. However, as Butterfield has pointed out, it is difficult to unequivocally evaluate the required oxygen levels necessary for the evolution of metazoans, nor is the geochemical evidence easily interpreted (Catling et al. 2005; Butterfield 2009). Of course, attaining higher oxygen levels is no guarantee that complex animals will evolve, but it may function as a threshold. Oxygen is

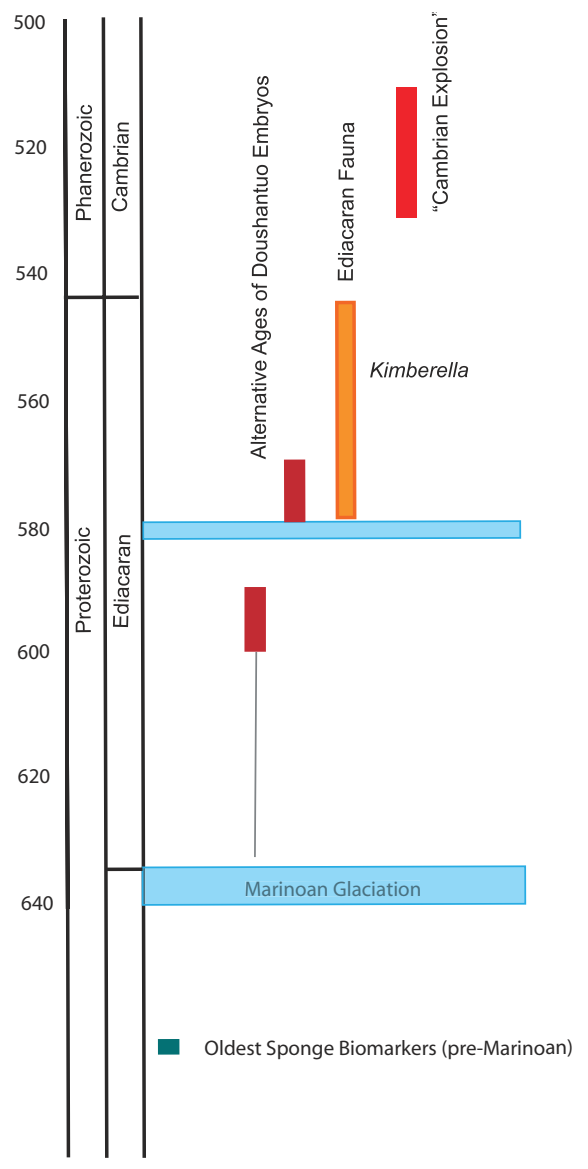

Figure 2. Timescale, geologic framework, and key fossil events associated with the evolution of Eumetazoa. The durations of the Sturtian and Marinoan glaciations are not well constrained, although the end of the Marinoan is well dated. Each may contain multiple events. The duration of the Gaskiers glaciation at 580 mya appears to be relatively short. Some organic walled remains from the Doushantuo that may be fossil metazoan embryos (Tianzushania) date to soon after the Marinoan glaciation, as shown by the gray line. The age of the most fossil-rich horizons not well resolved, however, and two alternatives are shown: 1 , before the Gaskiers glaciation, or 2, following the Gaskiers. The Ediacaran fauna has been divided into three sequential but partly overlapping assemblages, which are not shown here. The position of the appearance of diverse skeletonized fossils and other metazoan assemblages in the Early Cambrian is shown as the "Cambrian Explosion."

also required for the biosynthesis of collagen (Towe 1970). Although simple animals could have evolved with relatively low oxygen levels, even the construction of large sponges requires considerable oxygen levels in their immediate environment for the synthesis of collagen.

Geochemical evidence records a remarkable change in the redox state of the oceans during the late Neoproterozoic, shifting the oceans from a largely anoxic, and probably iron- and sulfur-rich state, to the predominantly oxygenated state found through the past 550 million years. This evidence comes from measurements of shifts in isotopic ratios of carbon, sulfur, and more recently other stable isotope systems, as well as other measurements. Geologic measurements of the ratio of two isotopes of car- 
bon, ${ }^{12} \mathrm{C}$ and ${ }^{13} \mathrm{C}$, chronicle shifts between two large carbon reservoirs, one consisting of organic carbon, including living organisms and their buried remains such as coal, peat, and oil, and the other of inorganic or carbonate carbon. Shifts in the carbon isotope ratio reflect changes in the burial of organic carbon or the release of previously buried carbon, among other causes. The carbon ratio is measured relative to a standard and is reported as $\delta^{13} \mathrm{C}$. The late Neoproterozoic and Early Cambrian interval is characterized by generally positive $\delta^{13} \mathrm{C}$ values, denoting the burial of organic carbon, punctuated by several very large negative $\delta^{13} \mathrm{C}$ anomalies associated with the glacial events. There is also a very large negative shift $\left(\geq 12 \% \delta^{13} \mathrm{C}\right)$ in the mid-Ediacaran that is not associated with any known glaciation. A number of geologists have interpreted this event as representing the final oxidation of the deep oceans (Condon et al. 2005; Fike et al. 2006). Other isotopic evidence, however, suggests that the oxidation may have occurred somewhat earlier, perhaps $~ 600$ mya (Canfield et al. 2008; Scott et al. 2008; Shen et al. 2008), and it is quite possible that the oceanic oxidation did not happen synchronously around the world, but instead in a staggered and regionally variable pattern (McFadden et al. 2008), ending near 555 mya. Highly variable carbon isotope ratios persist through the Early Cambrian, with the extreme anomalies gradually declining to levels typical of the post-Cambrian (Halverson et al. 2006).

Geochemical and geologic evidence indicates that environmental conditions during the deglaciation phase were quite severe. Sturtian and Marinoan glacial debris are overlain by unusual carbonate deposits indicative of rapid deposition in highly alkaline seas, probably during an intense climatic greenhouse interval (Crowley et al. 2001; Higgins and Schrag 2003; Corsetti et al. 2006). The various eukaryotic lineages that survived these glaciations must have been able to persist in refugia in the face of the extensive glacial episodes and the harsh postglacial phases. The Gaskiers event at 580 mya seems less likely to have had a severe impact on diversity.

\section{Earliest Fossil Evidence of Metazoans}

Preserved biomolecules, or biomarkers, provide the earliest evidence for metazoans. Pre-Marionoan deposits from Oman contain the degraded remains of $\mathrm{C}^{30}$ sterols, a sterol found today only in demosponges (Love et al. 2009). There is no evidence of such biomarkers near the Sturtian glaciation, but this evidence suggests that demosponges must have evolved before 635 mya.

\section{The Doushantuo Biota}

The Doushantuo Formation in southern China contains a diverse and exquisitely preserved suite of algae, organicwalled microfossils, and metazoan embryos, providing the best fossil evidence of early metazoan diversification (Fig. 3) (Xiao and Knoll 1999, 2000; Chen et al. 2000, 2002, 2004, 2009a,b; Xiao 2002; Hagadorn et al. 2006). These fossils reveal a wealth of cellular and often subcellular structures and a variety of different cell numbers (up to
2600 cells). The oldest described probable metazoan embryo is Tianzhushania, found just above the Marinoan glaciation but continuing through most of the younger parts of the Doushantuo formation (Yin et al. 2007). Assuming that the older specimens, which are known only from their external structure, are internally multicellular as clearly are the younger forms, these would be the oldest fossil metazoans so far unearthed. Given the harsh environmental conditions of the early Ediacaran, the presence of protecting structures surrounding metazoan embryos is not surprising, and indeed, this type of fossil embryo disappears from the fossil record $~ 550$ mya, coincident with the oxygenation of shelf waters (Cohen et al. 2009). As with many fossil assemblages, preservational problems pose many difficulties in distinguishing the original morphology from subsequent alteration (Xiao and Knoll 2000; Dornbos et al. 2006). That the Doushantuo microfossils represent animal embryos is certain, but preservational problems do pose challenges in establishing their phylogenetic affinities.

The Doushantuo microfossil assemblage is unusual in that the preservation conditions allowed fossilization of soft cellular structures. The major feature of this assemblage is the diversity of probable eumetazoan forms implied by even the limited amount of evidence so far available. Figure 3 provides some examples. Here we see, for example, well-preserved adult forms, albeit microscopic in scale, of two different cnidarian clades: a chambered coral similar to some known from the Cambrian and a possible hydroid-like organism (Chen et al. 2002). Figure 3C shows a bilaterally organized, probably coelomate animal fossil Vernanimalcula, that is only $\sim 200 \mu \mathrm{m}$ long but appears to be triploblastic (Chen et al. 2004a,b). Although this form is only known from sections, a number of additional specimens have now been recovered (D.J. Bottjer, unpubl.). The largest amount of evidence relevant to our considerations here is from synchrotron X-ray tomographic (SXRT) studies of fossilized embryos from the Doushantuo formation (Chen et al. 2006, 2009a,b; Hagedorn et al. 2006). Many specimens of near-identical morphology and dimensions have been reported for each of the embryonic forms illustrated in Figure 3. Figure 3D and D2 show computational sections of a frequently occurring, probably noneumetazoan, chorionated embryo that has a unique cleavage pattern similar to that of some modern sponge eggs (Chen et al. 2009a). A cleavage-stage embryo that forms polar lobes, as do a variety of modern protostome eggs, is reproduced in Figure 3E (Chen et al. 2006), and another unique cleavage form known today in acoel worms is illustrated in Figure 3F (Chen et al. 2009a). The successive computational SXRT sections display, from the "vegetal" side, two macromeres, and orthogonally arranged on the opposite side are four micromeres. Figure $3 \mathrm{G}$ shows a hollow gastrulating form, possibly cnidarian (Chen et al. 2009a). Finally, among many other forms that could have been included, Figure $3 \mathrm{H}$ shows a complex, later-stage bilaterally organized embryo with clearly diverse cell types, including macromeres, micromeres, and a central cord of possibly endodermal cells (Chen et al. 2009b). Clearly, what is thus far missing are the adult forms that produced all of these and the many further types of 

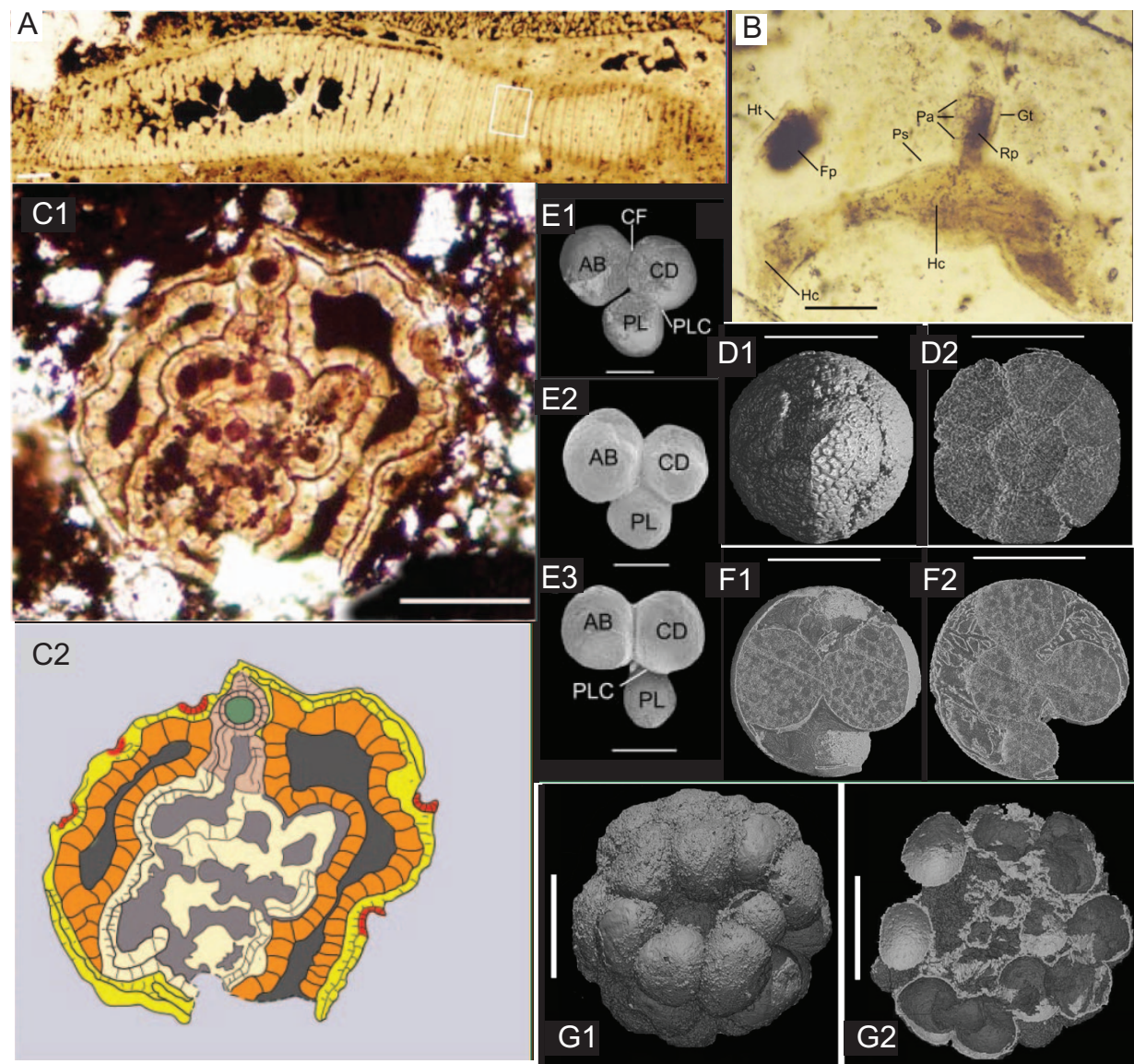

D1
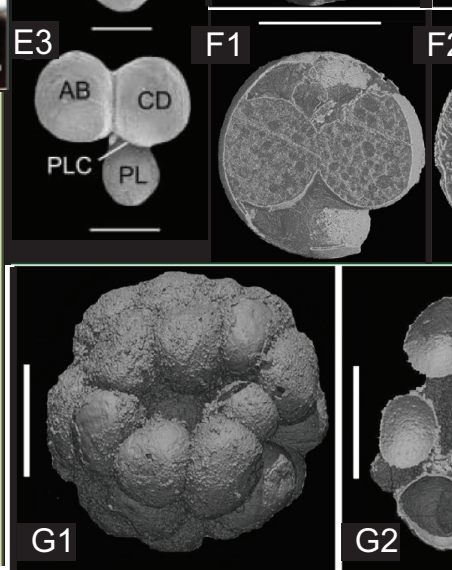

D2
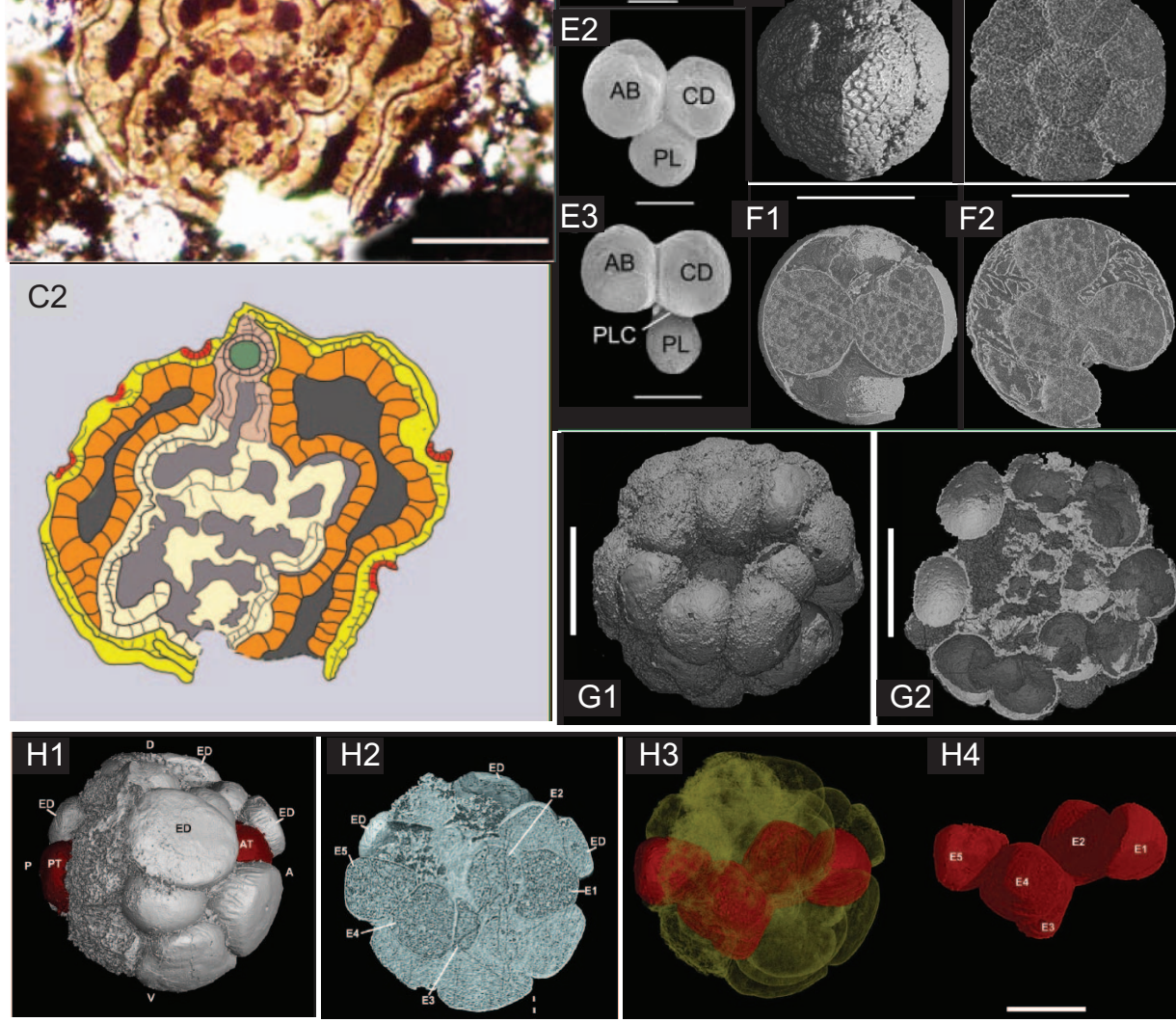

Figure 3. Fossil metazoans from the Doushantuo Formation, China. $(A-C)$ Visualizations of stereomicroscope sections. $(A)$ Colony of Sinocyclocylicus guizhouensis, a tabulate coral-like animal. Bar, $50 \mu \mathrm{m}$. (B) Hydrozoan-like animal. Features: (Gt) Gonotheca, (Pa) Perisarc annuli, (Ht) hydrotheca, (Ps) perisarc, (Rp) possible reproductive polyp, (Fp) possible feeding polyp, (Hc) hydrocaulus. Bar, $100 \mu \mathrm{m}$. (C1) Specimen of Vernanimalcula guizhouena; digital image of 50- $\mu \mathrm{m}$-thick section. Bar, $40 \mu \mathrm{m}$. (C2) Interpretation: (Orange) Mesodermal coelomic layer, (pink) pharyngeal structure, (green) mouth, (tan) endodermal gut with inclusions, (yellow) ectodermal layer, (red) surface pits. $(D-H)$ SEM (scanning electron microscope) and SXRT (synchrotron X-ray tomography) computational sections. (DI) External SEM of chorionated embryo; note cellular imprints each bearing a pit, possibly site of a cilium,with chorion partly broken to reveal surface of embryo below. (D2) Same embryo seen in medial SXRT section, revealing a central blastomere surrounded by six external blastomeres (16-cell stage). Bar, $400 \mu \mathrm{m}$. (E1-E3) Individual "trefoil stage" polar lobe cleavagestage embryos, viewed by SEM. Bar, $250 \mu \mathrm{m}$. $(F 1, F 2)$ Successive SXRT sections of a chorionated 6-cell cleavage-stage embryo, viewed from "vegetal" or large macromere duet end. Note prominent inclusions in macromeres that probably represent yolk platelets. Bar, $400 \mu \mathrm{m}$. (G1) External SXRT view of advanced embryo, polar view of site of invagination, (G2) medial section of same embryo showing blastocoelar cavity containing individual ingressed cells. Bar, $250 \mu \mathrm{m}$. (H) Complex later-stage embryo; (A) anterior, (P) posterior, (E) endodermal cell, (V) ventral, (D) dorsal, (ED) ectodermal cell. (H1) External view, from right side, (H2) SXRT section 43\% in from right surface, showing distinct putative endodermal cell types, $(H 3)$ transparent SXRT view from right side, endodermal cord colored in red, (H4) computationally isolated endodermal cord. Bar, $250 \mu \mathrm{m}$. (A,B, Reprinted, with permission, from Chen et al. 2002 [C Elsevier]; $C$, reprinted, with permission, from Chen et al. 2004a [C AAAS]; $D, F G$, reprinted, with permission, from Chen et al. 2009a [@ Elsevier]; $E$, reprinted, with permission, from Chen et al. 2006 [@ AAAS]; $H$, reprinted, with permission, from Chen et al. $2009 \mathrm{~b}$ [C National Academy of Sciences].)

embryo, but even so, their diversity is incontrovertible, and their topologies are known today only in eumetazoans. Overall, the evidence suggests strongly that animal life of several eumetazoan clades was already extant.

The base of the Doushantuo formation is well dated at 635 mya, and radiometric dates and fossils establish a
Cambrian age for the uppermost rocks. The age of the layers of the Doushantuo rich in fossil embryos is less certain, however. Integration of $\mathrm{U}-\mathrm{Pb}$ geochronology from China, Oman, and Namibia, stratigraphic correlations in south China, as well as $\delta^{13} \mathrm{C}$ data suggest that the Doushantuo fossils are younger than the Gaskiers glaciation at 
580 mya, and thus broadly correlative with the soft-bodied Ediacaran biota (Condon et al. 2005). These results conflict with earlier reports of $\mathrm{Lu}-\mathrm{Hf}$ and $\mathrm{Pb}-\mathrm{Pb}$ dates from phosphorites of the Doushantuo Formation that yielded dates of $602 \pm 48$ and $599 \pm 4$ mya, respectively (Barfod et al. 2002). However, these analyses are wholerock analyses of diagenetically altered phosphorites and use systems that can be less reliable than $\mathrm{U}-\mathrm{Pb}$ radiometric dates. Black shales between the fossiliferous upper and lower phosphorite beds were recently dated by $\mathrm{Pb}-\mathrm{Pb}$ methods to $572 \pm 36$ mya (Chen et al. 2009c). This discrepancy has not been resolved and we simply note two alternatives: (1) dates of 600-590 mya for the Doushantuo fossils or (2) post-580 mya (see Fig. 2).

\section{The Ediacaran Biota}

A morphologically diverse suite of macroscopic softbodied fossils is found in rocks from many parts of the world dating from 579 to 542 mya (Figs. 2 and 4). These fossils consist of a variety of discs, fronds, and more complex forms, some exhibiting apparently bilateral symmetry (such as Dickinsonia and Yorgia, illustrated in Fig. 4) (Gehling et al. 2005; Narbonne 2005; Fedonkin et al. 2007a; Xiao and Laflamme 2008). None of the published fossils exhibit evidence of a mouth, appendages, or other morphological structures indicative of phylogenetic affinities of protostomes or deuterostomes. Indeed, recent comparative developmental studies are consistent with all of these fossils representing clades between sponges, at the origin of metazoan, and the acoels (Erwin 2009).

Kimberella, found in rocks dating to 555 mya (Martin et al. 2000), is the notable exception. Kimberella is an oval fossil, $\sim 5 \mathrm{~cm}$ in length, with an apparently muscular foot surrounded by crenulated depressions that likely represent some sort of a frill (Fig. 4D). A number of specimens preserve signs of a proboscis, plausibly in the anterior end of the animal. Specimens of Kimberella are often associated with radiating, parallel scratch marks that have been interpreted as indications of the animal feeding on a microbial mat (Fedonkin and Waggoner 1997; Fedonkin et al. 2007b). Although many of these features are similar to those of a mollusk (Fedonkin and Waggoner 1997), it is probably premature to assign Kimberella to the Mollusca. But this is convincing fossil evidence that the protostomedeuterostome ancestor likely predates 555 mya.

\section{Ediacaran Trace Fossils}

Trails and burrows are another form of fossil, in addition to the molecular fossils and body fossils already described. There is a rapid increase in the diversity and complexity of trace fossils after 560 mya, in the latest Ediacaran and Early Cambrian. Most Ediacaran trace fossils are poorly organized, meandering, horizontal forms laid down on the surface of the sediment. A more complex form, Helminthorhaphe from South Australia, has a relatively tight spiral meander connected to a more random trail. The complex spiral suggests a moderately well-developed sensory system in a bilaterian animal. Although many papers have described a variety of Ediacaran trace fossils, some of which appear to have been generated by bilaterians, recent reanalyses indicate that the oldest valid metazoan trace fossils date to 560-555 mya (Jensen et al. 2005, 2006), roughly coincident with the first appearance of Kimberella. Not until the very end of the Ediacaran do we find any vertical, penetrating burrows, indicating the first appearance of organisms with a hydrostatically resistant coelom. Numerous paleontologists have used these burrows as an indication of the presence of the organisms of the grade of modern protostomes. Because acoel flatworms are bilaterians, primitive bilaterians were probably small and lacked a coelom. In addition, paleontologists have recently recognized a suite of tubes that represent body fossils, rather than trace fossils, and which appear to be bilaterian, but the phylogenetic affinities of the organisms that produced these tubes are

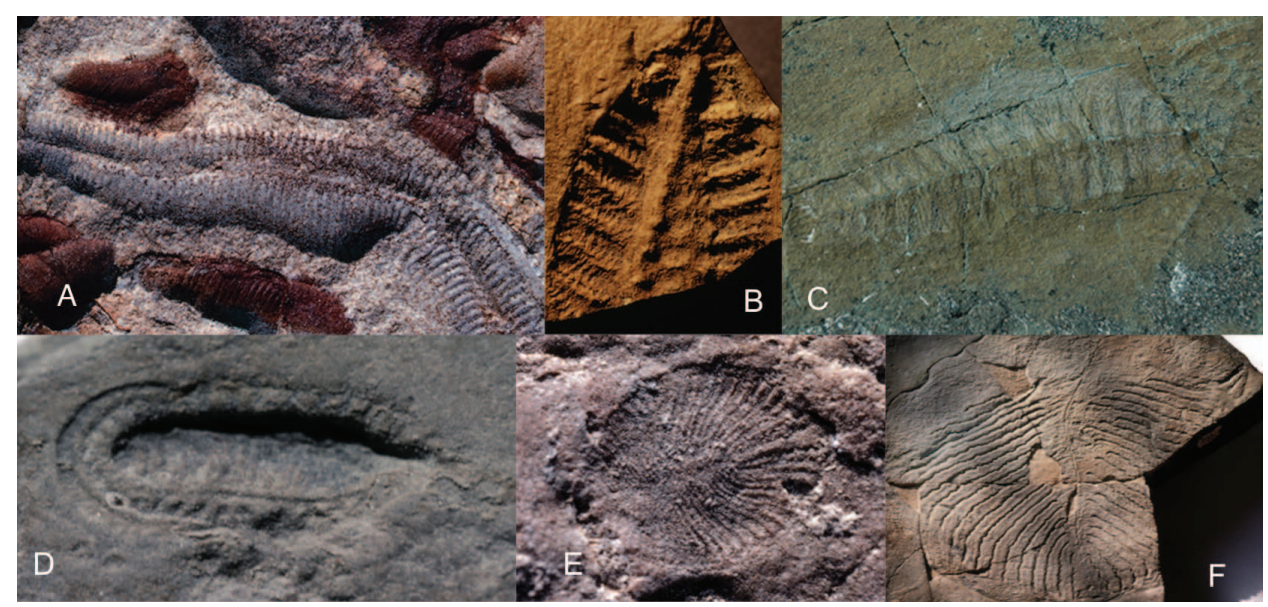

Figure 4. Ediacaran soft-bodied fossils. (A) Pteridinium from southern Namibia; image is $\sim 1$ foot across. (B) Portion of a frond of Rangea from southern Namibia; specimen is 3.5 inches long. (C) Fractofucus, a rangeamorph from Mistaken Point, Newfoundland; specimen is $\sim 4$ inches long. (D) Kimberella, probably bilaterian, from the White Sea, northwestern Russia, anterior to the right. (E) Dickinsonia from South Australia, 2 inches long. $(F)$ Yorgia, from the White Sea, Russia; the asymmetric anterior shield is in the upper part of the image, $\sim 4$ inches across. Photographs by DHE. 
unknown. Because discrete trace fossils less than $\sim 1 \mathrm{~cm}$ in diameter do not necessarily preserve well, their record suggests that benthic bilaterian animals larger than this size were not present until after $~ 560$ mya, although smaller bilaterians could well have been present ealier.

In summary, the fossil record demonstrates that the origin of metazoans predates 635 mya, consistent with evidence from molecular clocks. The Ediacaran-age Duoshantuo Formation from South China contains wellpreserved fossil embryos of various stages, consistent with a variety of animals above cnidarians on the phylogenetic tree. We cannot yet be certain whether the diverse metazoan Doushantuo embryo assemblages date from 600-590 mya or are younger than 580 mya. The phylogenetic affinities of the soft-bodied Ediacaran biota (579-542 mya) are complex and represent a variety of lineages. We view them as a series of clades arising independently along the metazoan backbone. Although the morphology of several of the clades, particularly the Dickinsoniamorphs, seem to be superficially bilaterian, so far only Kimberella shows convincing bilaterian characters. Geochemical measurements indicate that the deep oceans had become well oxygenated $~ 555$ mya, and the appearance of Kimberella and the oldest metazoan traces at this time is unlikely to be a coincidence.

\section{INTEGRATION OF FOSSIL AND DEVELOPMENTAL DATA WITHIN THE PHYLOGENETIC CONTEXT}

Phylogenetic and paleontological evidence provides a new perspective on the genetic regulatory structure of deep time eumetazoan evolution and the underlying bilaterian developmental process. Here, we view eumetazoan evolution through the lens of the structure of the developmental GRNs (dGRNs) that have recently been solved. We then attempt to integrate the conclusions from this kind of information with those emerging from the preceding discussion.

\section{The Developmental Perspective}

Although the body of evidence is yet slim, comparison of the few relatively well-known and extensive dGRNs for which we have embryonic development reveals certain common structural properties. As examples, this pertains to the dGRN for the Drosophila dorsoventral system (Stathopoulos and Levine 2005); the sea urchin embryo skeletogenic mesoderm dGRN (Oliveri et al. 2008) and anterior and posterior endoderm dGRNs (Peter and Davidson 2009a,b); the dGRN for Xenopus dorsoventral specification (Koide et al. 2005); and gut-lineage specification in Caenorhabditis elegans (Owraghi et al. 2009). Each of these dGRNs consist exclusively of genes encoding transcription factors and signaling molecules and the functional cis-regulatory linkages among them. Their general characteristics include the following:

1. They are many layers deep, i.e., they extend from the initial spatial inputs, which in each case initiate the zygotic cascade of transcriptional expressions, to terminal states of cellular specialization in embryonic space.
2. Their depth follows from the different kinds of subcircuits they include, viz. subcircuits that install the initial state of specification in the respective spatial domains, subcircuits that then lock down the specification state, subcircuits that exclude other specification states, subcircuits that operate intercell signaling systems, and finally, subcircuits that run differentiation gene batteries (for review, see Davidson 2006; Peter and Davidson 2009b).

3. They are hierarchical and determinate, in that at each stage, the upstream subcircuits determine the activity (or silence) of those in the next step downstream.

4. They involve, for each "component" of the developmental process, on the order of 20-50 different regulatory genes.

5. But these same regulatory genes are usually found wired into other dGRNs in the same genome. Regulatory genes operate at multiple times and places where they use entirely different input connections; like signaling systems, transcription factors are used continuously in the life cycle and almost none are dedicated to single developmental events. dGRNs control the formation of very disparate kinds of structure. Development by the pathways used in all well-known examples requires execution of the variety of regulatory "jobs" that dGRN subcircuits do. A conclusion that is unlikely to be far wrong is that the development of any eumetazoan embryo or postembryonic body part is likely to be controlled by dGRN components of similar depth, complexity, and subcircuit diversity. The difference between is often called a "more complex animal" and a "less complex animal," to the extent that if there is any difference in the underlying dGRN structures, it probably lies in the number of dGRN components required to build the body plan of the animal. This will depend on the number of qualitatively different body parts, stages, and morphological features for which the development of the body plan has to account. But each dGRN component will have the depth and other characteristics enumerated above, i.e., in comparing diverse animals, the depth per dGRN component will be similar, but the number of these, or the breadth, will vary.

The general quality of eumetazoan dGRN structure requires that there must have been preceding stages in dGRN evolution, in which the dGRN complexity was lower, the depth shallower, the variety of subcircuits less, and hierarchy less dominant a feature. In the following sections, we expand on the subject of dGRN evolution per se. Our point here is that if eumetazoan body plans require deep dGRN wiring, developmental regulatory programs structured in this way must have preceded the divergence of the eumetazoa. The obverse is that animals lacking these program characteristics were not eumetazoans.

\section{Bilaterian Evolution}

The "Bilateria" have traditionally been thought of as the clade of animals descended from the last common protostome-deuterostome ancestor. Aside from the issue 
of whether the protostomes are really a monophyletic clade, the phylogeny discussed above destroys this equivalence: The Bilateria must encompass the acoels, yet the acoels lie outside the clade composed of protostomes plus deuterostomes. This leads to the realization that these characters appeared in evolution piecemeal, in organisms that also display nonbilaterian characters (Fig. 5). The cnidarians are the great example: As has been pointed out (Technau 2001; Finnerty et al. 2004; Martindale et al. 2004; Technau et al. 2005; Putnam et al. 2007; Hejnol and Martindale 2008), in development of the most basal cnidarian clade, anthozoans, regulatory genes are expressed in bilateral axial patterns that indicate an underlying set of bilateral regulatory states. Furthermore, these patterns include examples of regulatory genes expressed in relative positions reminiscent of the patterns of expression of the same genes in bilaterian development. Cnidarians seem to possess almost the complete bilaterian regulatory gene tool kit, including anterior and posterior hox genes (Finnerty et al. 2004; Putnam et al. 2007) and generate many of the ectodermal, neuronal, endodermal, and mesodermal differentiated cell types also found in bilaterians. Yet, the same genomic regulatory systems encode the nonbilaterian features of anthozoan larvae and adults as well. Similarly, the acoels have many features of other bilaterians, but unlike the basal body plans of protostomes and deuterostomes, they use a blind rather than a through gut and have other special characters (Baguña et al. 2008).

Thinking of the bilaterian character suite as the result of a gradual assembly process changes our expectations of the phylogenetic breadth of Ediacaran assemblages. As noted above, this first macroscopic animal fossil assemblage is very diverse. We might expect it to include then current representatives of all the eumatazoan clades: cnidarians, acoel grade bilaterians, protostomes, and deuterostomes, and perhaps now-extinct clades that possessed some but not all bilaterian characters. There is a potent underlying mechanism devolving directly from the nature of eumetazoan dGRNs that will result in the appearance and persistence of given diverse clades

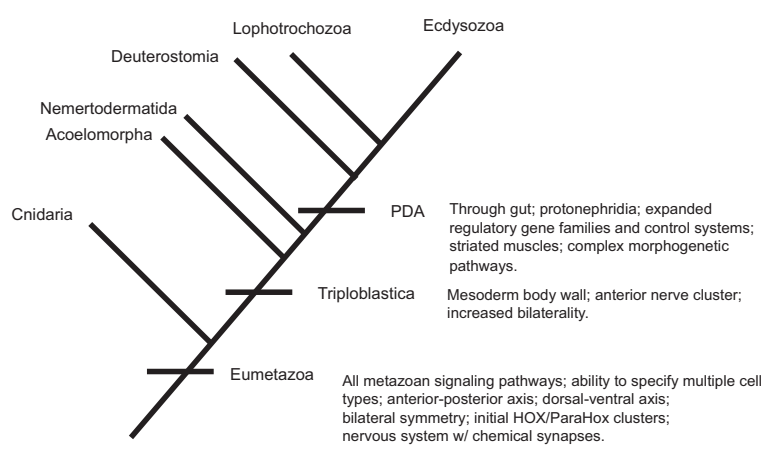

Figure 5. The sequential assembly of bilaterian characters was a gradual process. Both the developmental tools and the morphologic characteristics of Bilateria were sequentially adopted during early metazoan evolution. Key features are shown at relevant nodes. (instead of a continuous array of morphotypes). This is the canalization of developmental regulatory process in each lineage, i.e., once the upper-level subcircuits in the hierarchical dGRN have emplaced regulatory states in respective portions of the organism, fundamental aspects of the body plan are fixed in each lineage.

\section{Eumetazoan Lineages and dGRN Kernels}

Canalization of developmental processes in eumetazoan lineages means that the responsible upper-level subcircuits will be evolutionarily conserved in all descendants of the ancestor of that lineage. Upper-level subcircuit conservation is the other side of the coin of canalization. Our dGRN kernel concept (Davidson 2006; Davidson and Erwin 2006; Erwin and Davidson 2009) originated in considerations of extremely conserved dGRN subcircuits, which in the development of modern animals determine the early regulatory states for given progenitor fields, i.e., kernels cause expression of regulatory genes that together define a previously undetermined area of cells as the domain where a certain developmental outcome will ensue. For example, two cases that we discussed in earlier work concerned an extremely conserved kernel that is involved in setting up endoderm specification in very distant members of the echinoderm phylum (Hinman et al. 2003) and a kernel at the top of the dGRN for heart specification that is very similar from Drosophila to vertebrates (Davidson 2006). Another echinoderm-specific kernel has been discovered that underlies embryonic mesoderm specification (McCauley et al. 2009). Consideration of the evolutionarily canalizing upper-level subcircuits of dGRNs leads to the idea of dGRN kernels, just as does the observation of real, unusually conserved upper-level dGRN subcircuits in modern animals. Thus, the discrete forms of eumetazoan body plan must be built by circuits (i.e., kernels) high up in the structure of the dGRN that are the same in all members of each clade, because they all share the developmental outcome of the clade-specific body plan. It is interesting that in the (few) cases known, the several genes of the kernel subcircuit have acquired multiple internal feedback linkages ("recursive wiring"; Erwin and Davidson 2009), so that interference with expression of any of them by mutation or experimental manipulation has severe effects on the phase of development that they initiate. This accentuates the selective conservation of the whole subcircuit, on pain of developmental catastrophe.

We must emphasize that as we envision it, there is nothing unusual about the initial formation of kernels as opposed to other subcircuits of the eumetazoan dGRN; what is unusual is the role that they have downstream because of their hierarchical position in the dGRN once they are formed. This role has strong phylogenetic implications. By canalizing the possibilities of development downstream, kernels essentially define the "developmental morphospace" within which developmental variation is allowed. If, for example, a kernel sets up the initial regulatory state leading to endoderm specification in a given patch of cells, development is canalized in the sense that the only fates allowable in that patch of cells are endoder- 
mal, and the morphospace for future variations in the structure of the gut is defined. Taxonomic clades are defined by the structures emerging from these same spatial elements of the body plan. Therefore, these clades must reflect the assignment of specification states for spatial elements of the body plan by dGRNs (Davidson and Erwin 2006). dGRNs represent the deep structure of developmental systems, and it is their hierarchical structure that is imperfectly reflected in the early 19th century hierarchical Linnaean concept of animal taxonomy. Categories of the Linnean taxonomic hierarchy are not always monophyletic clades (although they should be), but we might predict that the entities recognized as superphyla and phyla should be defined by kernels responsible for their morphological attributes. Similarly, class-specific kernels and perhaps lower-level kernels should exist as well (Fig. 6). Differences defining genera and species are smaller, i.e., they occur as the result of variations in dGRN wiring at lower levels of the hierarchy. These variations are at the level of deployment and nature of differentiation gene batteries and the deployment of signal-driven and other switch systems (Davidson and Erwin 2006). Because almost all variation in body plans since the Early Cambrian have been at the subphylum level, phylum- and superphylum-level kernels must have originated in the Late Neoproterozoic and perhaps Early Cambrian. By this argument, generation of class-level kernels must have continued at the least into the Ordovician.

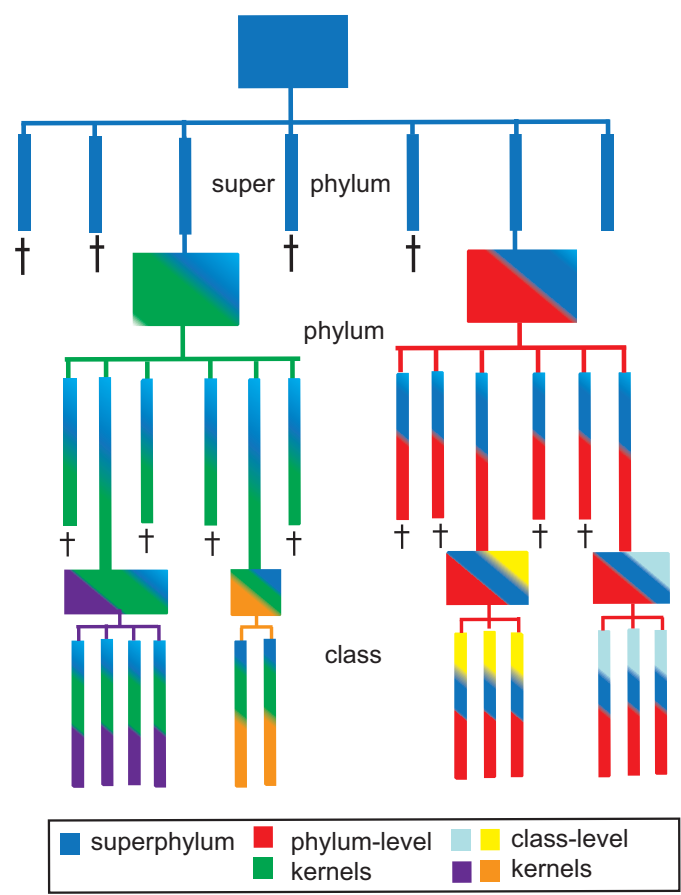

Figure 6. Kernels determining characters of the body plan at superphylum, phylum, and class levels. Each clade is represented by a vertical line. Each has perhaps the same number of total characters, but only those characters specified within the morphospace defined by the respective dGRN kernels are indicated by the color coding.

\section{BEFORE THE EUMETAZOA: INFERRED STAGES OF EVOLUTION OF DEVELOPMENTAL GRNS}

To imagine how the hierarchical eumetazoan dGRN with its clade-specific kernels at the top could have arisen, we need to take a conceptual journey backward and deconstruct the eumetazoan dGRN, considering the origins of each of its component types of circuitry.

\section{Initial Steps of dGRN Evolution}

We begin with the earliest dGRN subcircuits in evolutionary terms. These are differentiation gene batteries. The most basal extant metazoans, sponges (see Fig. 1), deploy a number of differentiated cell types. In terms of genetic regulatory circuitry, the simultaneous expression of diverse differentiation gene batteries in temporally coeval but spatially separate cellular domains is the fundamental property of metazoans (in contrast, for example, to singlecelled organisms that express different downstream genes at different times in their life cycle or in response to different external cues). Differential expression of downstream gene batteries is the simplest regulatory structure that can produce an organism composed of simultaneously present, diverse specialized cell types. The fundamental dividing line is that metazoans must execute spatial developmental gene regulation in order to direct the construction of regulatory states in different morphological compartments that must have a genetically specified geometrical relation to one another. We know enough about the control structure of differentiation gene batteries to infer the minimum regulatory requirements. Unlike the regulatory states produced by the deep dGRNs of eumetazoans, the regulatory states needed just to run differentiation gene batteries consist of only a very small number of transcriptional regulators that together drive the activity of all the downstream protein-coding genes of the battery (for review, see Davidson 2006). An additional requirement for the earliest developmental process deploying differentiation gene batteries is some form of developmental "address" that would cause activation of diverse driver regulators in particular domains of the multicellular structure. The address might consist, for instance, of spatial polarizations in distribution of molecules with gene regulatory activity. The many examples we have of polarizations of regulatory significance in eggs provide models of what we might expect to have been used for this purpose. To summarize, as indicated in Figure 7A, the minimal GRN for the construction of a multicellular animal expressing different differentiation gene batteries in different cellular domains is a relatively shallow structure, similar to the differentiation gene batteries that lie at the periphery of all modern dGRNs.

\section{Signaling, and the Augmentation of dGRN Architecture}

All modern bilaterian dGRNs deploy intercellular signaling in a variety of ways. Developmental signaling depends 
A
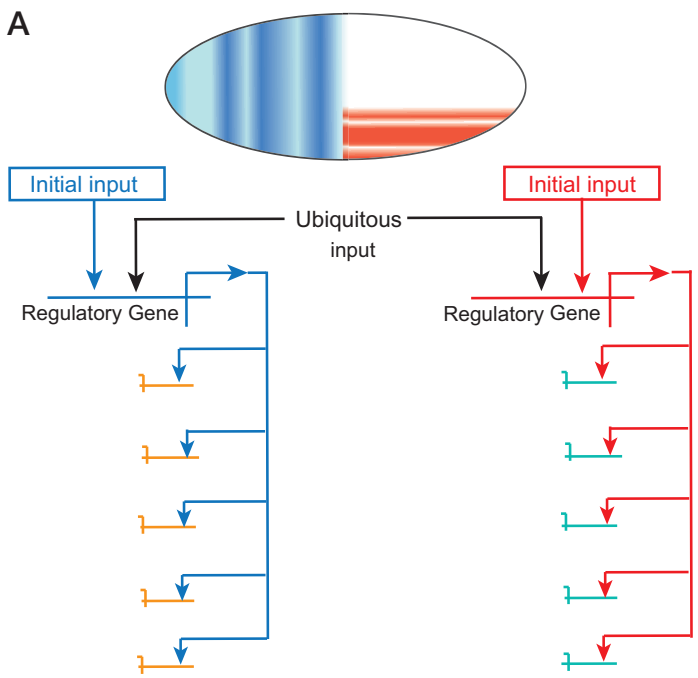

B

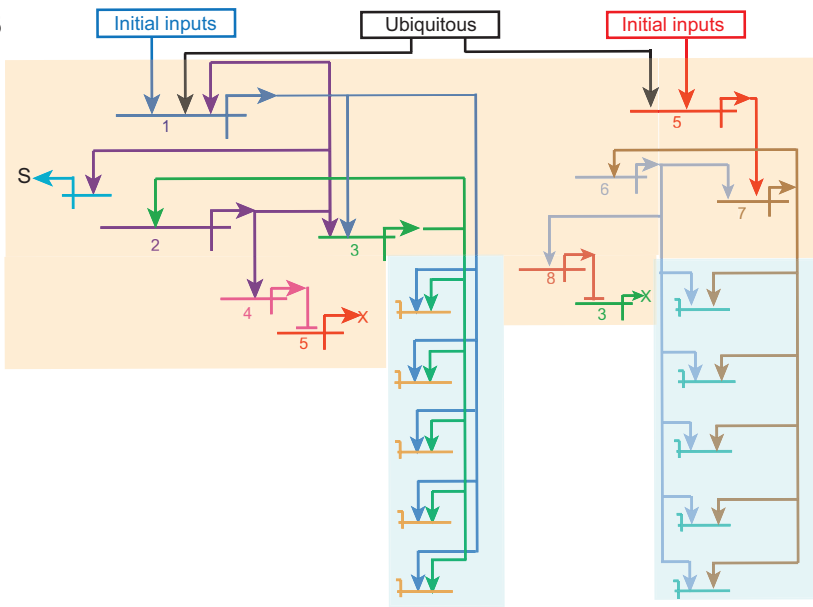

C

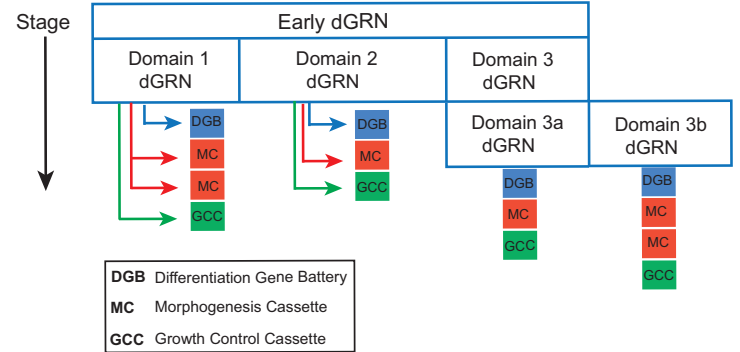

Figure 7. Stages in early dGRN evolution and downstream functional cassettes. (A) Initial stage (see text): Spatial inputs in a simple metazoan are used to activate transcriptional drivers of two different differentiation gene batteries. $(B)$ Later stage, illustrating intercalary network evolution. Intercalated circuitry is shown on a tan background and the same differentiated gene batteries as in $A$ on a lavender background. Genes 1 and 5 have the specific role of transducing the localized initial inputs that are the same as in $A$. Genes 2 and 3 and 6 and 7 set up feedback lockdown subcircuits stabilizing the regulatory states and providing for a stable generation of the differentiation gene batteries. Genes 4 and 8 repress key genes in the alternate regulatory state, i.e., genes 3 and 5, providing additional robustness of state. $(C)$ Downstream functional cassettes deployed due to regulatory inputs from the respective spatially active dGRNs: (blue) diverse differentiation gene batteries, (red) diverse morphogenesis cassettes, (green) cell cycle control cassettes.

mainly on a small set of continually reused signal ligandreceptor systems, each of which operates a signal transduction system the relevant biochemical targets of which are transcription factors. Signal systems affect development because they decisively alter the functional properties of their target transcription factors and thereby affect spatial expression of regulatory genes. A whole set of developmental signal systems are used for the development of every known bilaterian, with a few possible exceptions. Even choanoflagellates possess some of these signaling systems (King et al. 2003, 2008; Erwin 2009; Marshall and Valentine 2009) as do sponges, and they are all found in cnidarian genomes (Matus et al. 2007). This can be considered a "preadaptation" to the subsequent evolution of dGRNs (Marshall and Valentine 2009). Signaling systems may have been incorporated in dGRNs very early in their evolution. They are very useful, and it is interesting that the following list of their developmental uses could apply to the simplest levels of dGRN architecture:

1. Inductive signaling: Sending cells alter the regulatory state of receiving cells.

2. Global spatial control: Cells receiving the signal are allowed to express signal system target genes, whereas in all other cells, these same target genes are defaultrepressed by the same transcription factor that transduces the signal.

3. Community effect signaling: Cells within a territory express a regulatory state signal among themselves in order to uniformly maintain that regulatory state (Bolouri and Davidson 2009).

Figure 7B represents a later stage of dGRN evolution in which several subcircuit devices have been inserted that greatly increase the robustness and accuracy of the differential control system in Figure 7A. These include a feedback subcircuit that stabilizes the expression of the differentiation driver genes, a subcircuit that is dedicated to interpretation of the initial spatial inputs, which because of the feedback circuit may now be present only transiently, and a subcircuit that represses a key gene of the alternative territory. In addition, within each domain, community effect signaling could be operating (not shown), and each domain might express an inductive signal that can be used to specify an adjacent territory. We now have a more hierarchical, multifunctional, nascent dGRN. Note that the additional cir- 
cuitry has been inserted between the differentiation genes and the initial embryological address ("intercalary" evolution; Gehring and Ikeo 1999). This circuitry controls two stages of development: what we would call specification, i.e., setting up the regulatory state, and what we would call differentiation. It also carries within it the mechanistic possibility of inserting further stages and of further subdividing territories by deployment of signal systems using the same kind of subcircuit devices. Such continued processes can account for the evolution of the modern eumetazoan dGRN. An implication is that there could be a fixed repertoire of subcircuit topologies that have been incorporated over and over and over again as dGRNs evolve in depth and breadth. There is indeed beginning to emerge strong evidence for this from the comparative study of modern dGRNs (Levine and Davidson 2005; Davidson 2009; Peter and Davidson 2009a,b).

Something is still missing, however, and that is the control of morphogenetic functions. We know little of how the morphogenetic cassettes that generate cell movement, epithelial sheets, tubes, columns of cells, outgrowths, branching structures, invagination, etc., are structured or controlled. But clearly, they are linked to the upstream dGRNs (Christiaen et al. 2008), as are cell division control systems (for review, see Davidson 2006), because it is these dGRNs that determine their deployment and thus the morphology of the organism. The organism also has to operate physiological GRNs, for example, those that control its responses to immune challenge and environmental stress (Amit et al. 2009). Thus, in the end, the dGRN is the "brain" that determines the sequence of activation, location, and identity of the effector subcircuits of downstream genes that build the body plan of the organism (Fig. 7C).

Finally, in considering the assembly of the eumetazoan dGRN, a prominent feature of postgastrular development in the macroscopic modern bilaterians is the use of "vectorial" regulatory systems that act as switches to initiate or repress the activity of dGRN subcircuits in different regions of the body plan. Two very different kinds of these switches are diffusible molecules that affect gene expression, such as retinoic acid along the anteroposterior neuraxis and the hox gene system. The latter is used and reused as a set of vectorial patterning switches (for review, see Davidson 2001; Davidson and Erwin 2006) These systems are useful for controlling differences in regulatory state in serially reiterated domains and in organizing regulatory states in nested or contiguous spatial patterns. From the viewpoint of the dGRN, hox gene functions are in many of the most famous cases equivalent to what we have termed "input/output switches" with respect to those subcircuits of the dGRN that actually create pattern and deploy downstream morphogenesis cassettes and differentiation gene batteries. This role of hox genes is probably not to be considered an early, sine qua non evolutionary invention in the long history leading to the eumetazoan dGRN. For example, the sea urchin larva, a small, bilateral free-living organism, develops without ever deploying its hox gene complex (Arenas-Mena et al. 1998), which is used only later in generating the macroscopic adult form.

\section{MECHANISTIC ASPECTS OF DGRN EVOLUTION: CHANGE AT THE DNA LEVEL}

The basic mechanism of invention, and of every kind of structural change in dGRNS, is cis-regulatory alteration of the control systems of regulatory genes. These alterations either provide genes with new target sites and thus new inputs (i.e., forming new GRN linkages) or destroy preexisting target sites (i.e., breaking prior GRN linkages). As we have discussed recently elsewhere (Davidson and Erwin 2009), this kind of change converges on the process underlying the evolutionary phenomenon of "cooption," which denotes redeployment of regulatory gene expression to a novel spatial and/or temporal locus in development. In considering formulation of new dGRN circuitry, as in the progression from the grade of organization in Figure 7A to that in Figure 7B, the whole process boils down to acquisition of new cis-regulatory inputs in preexisting regulatory genes. A hidden presumption here is that the regulatory gene tool kit per se is preexistent, and this is now clearly supported by the results of genome projects and other data (Erwin 2009; Marshall and Valentine 2009). There has long been a conceptual disconnect between the continuous mechanism of evolution inferred from traditional protein evolution population genetics, in which phenotypic change is attained when a genetic alteration becomes homozygous, and the kind of process that follows from regulatory gene cooption. In the first place, formation of a new GRN linkage can obviously produce large regulatory, i.e., developmental, effects (or no effects; Davidson and Erwin 2009). But in addition, cooptive change is essentially a regulatory gain-of-function event, and this has profound consequences. As first pointed out by Ruvkun et al. (1991) and further discussed by ourselves (Davidson and Erwin 2009), extensive laboratory experiments show that regulatory gene gain of function is usually a haplodominant event. Particularly in embryonic development, expression of a single copy of a regulatory gene usually suffices to support downstream dGRN function (or else we would not have all the regulatory genes discovered in haploid mutant screens!). The evolutionary significance is that regulatory change in dGRN structure suddenly becomes a likely rather than an impossibly unlikely event, judging from the high rate of cis-regulatory change we observe by comparing related modern organisms. Each lineage of animals descended from a founder bearing a haploid regulatory gain of function will likewise express that function, which will thus be available to be combined with such further changes.

\section{Subcircuit Assembly: How Do dGRNs Get Built?}

In considering this question, the functional character of modern dGRNs must be our primary guide. Here, the most important feature is that dGRNs are modular in structure: The unit "jobs" of development are performed by individual subcircuits, as discussed above. The form of a dGRN consists of the sum of its particular subcircuits plus the morphology of the switches and other connections among the subcircuits. So our problem is to establish how subcircuits can be assembled by a process of (haplodominant) regula- 
tory gene cooption. Typical subcircuits consist of three to six genes with many more linkages, because each gene has multiple inputs. In the process of subcircuit assembly, preexistent linkages and preexistent cis-regulatory modules or enhancers may often be used (sometimes after duplication), but at a different address due to insertion or mutational creation of new target sites. Cis-regulatory modules have many sites for ubiquitously present factors that perform mechanistic functions other than determining when and where the module will be active (e.g., mediating intermodule interaction, looping to the basal promoter, and amplifying regulatory output, etc; see, e.g., Yuh et al. 2001). Thus, addition of a new site is likely to be functional in the proximity of, or within, a preexistent cis-regulatory complex. But another evolutionary aspect to consider is at the level of the whole genome. As different developmentally localized dGRNs for various aspects of development accumulate in the genome, providing increasing overall dGRN breadth, the genome contains a larger and larger repertoire of already extant subcircuits that can be "highjacked" and coopted to a new function by relatively small changes that alter the deployment of the subcircuit as a whole. This predicts that as the global regulatory system becomes more complex, the possibilities of dGRN change will increase sharply.

An example from comparison of modern dGRNs will illustrate some of these points. In the evolution of echinoids (sea urchins), the euechinoid and cidaroid lineages diverged perhaps 275 mya (Littlewood and Smith 1995). The euechinoid lineage makes an embryonic skeleton from a precociously specified embryonic cell lineage and the cidaroid lineage does not. The euechinoid dGRN controlling specification, development, and differentiation of the skeletogenic lineage is well known (Oliveri et al. 2008). This very complex dGRN, which includes $\sim 25$ regulatory genes, must have appeared in the genomic control system for embryogenesis since divergence of these echinoid clades. In a effort to determine its evolutionary origin, we discovered that the entire skeletogenic network was highjacked from the portion of the genomic regulatory system that controls adult skeletogenesis (spines and body wall plates; Gao and Davidson 2008). This network was grafted onto the initial specification apparatus that defines the initial regulatory state of the skeletogenic founder cell lineage. In addition, four regulatory genes not used in adult skeletogenesis were coopted for participation in the embryonic skeletogenic system. All that might have been required to accomplish highjacking of the adult skeletogenic subcircuit was insertion of sites for a single (repressive) transcription factor in the cis-regulatory modules of three genes at the top of the adult skeletogenic network.

\section{Rates of Morphological Change}

The evolution of eumetazoan body plans by the kinds of alterations in dGRNs discussed here implies that, over time, rates of change in morphology will vary greatly. This is, in fact, just the pattern of change seen in studies of morphological diversity (disparity) in the fossil record (for review, see Erwin 2007). The maximum rates of increase in disparity generally occur near the origin of a clade, with much of subsequent evolution largely "filling in" the morphospace defined by the initial diversification. Part of the explanation must be ecologic, and during the initial diversification of the eumetazoan clades, positive feedback must have occurred between organisms and their environment. In a word, as animals diversified, they altered the environment, producing more selective opportunities for more animal diversification (Erwin 2008). As with any positive feedback, the expected consequence is sharp acceleration of the process. Turning to the nature of change within dGRNs, a primary mechanism for rate variation derives from the developmental morphospace concept (see above). In the initial phase, as morphospace downstream from a newly evolved spatial specification system is filled in, all the variety of allowed solutions will appear, if selectively viable, but thereafter, dynamic stasis will ensue. The expected result is indeed similar to the rapid variation in morphology followed by long stability canonically observed in the fossil record. We have also suggested that there is an additional feature of crown group dGRNs that contributes to morphological stasis, and that is their deeply "overwired" regulatory circuitry. Such circuits prevent any deviation from the correct developmental outcome, by means of multiple regulatory devices that not only produce a given developmental result, but also actively prohibit alternative possibilities (Davidson and Erwin 2009; Peter and Davidson 2009a; Smith and Davidson 2009). In general, the evolutionary consequence would be to buffer these systems against further change. But at the same time, this also means that during the early diversification of eumetazoans, the dGRNs would have lacked some of the fail-safe devices we now see and they would have been more flexible, allowing the generation of a greater variety of morphologic novelties.

In contrast to large-scale morphological evolutionary change, traditionally recognized as the origination of new phyla, classes, and orders of animals, changes at the periphery of the dGRN can happen rapidly. There are now several justly famous cases where dramatic morphological changes that have occurred very recently have been shown to be due to alteration in regulation of single genes, encoding either signaling ligands (Abzhanov et al. 2006) or transcription factors (Cretekos et al. 2008; Chan et al. 2009; Rebeiz et al. 2009). The periphery of a dGRN is a different place from its interior, where multigenic subcircuits do the work, embedded in regulatory linkages upstream and downstream, and frequently interlaced with feedbacks. As we have discussed elsewhere (Erwin and Davidson 2009), change at lower taxonomic levels occurs by redeployment of switches, often signaling switches, and by redeployment of differentiation gene batteries and change of protein-coding genes within such batteries. These kinds of events affect the periphery of the dGRN and late processes in the morphological development of the animal. In a regulatory sense, the underlying DNA-level changes are located far from the constraints that for hundreds of millions of years have defined the cladespecific morphospace of modern bilaterian lineages at higher taxonomic levels.

In conclusion, evolution of eumetazoan body plans has not been a uniform process. The nature of allowable genetic change in dGRNs during the early diversification of 
eumetazoans channeled the construction of the highly structured regulatory networks responsible for key developmental events. Today, much evolution involves the peripheral modification of these networks, not their construction, and is no more similar to early dGRN evolution than is the modern environment to Neoproterozoic environments. Although we still have much to learn about the timing of the earliest phases of eumetazoan evolution, and we look forward to resolving the phylogenetic position of ctenophores and other groups, enough information is available to sketch the relationship between these events and environmental changes in the late Neoproterozoic. Figure 8A illustrates minimal divergence times based exclusively on a strict reading of the fossil record, assuming the later dates for the Doushantuo, showing most metazoan evolution occurring during the second half of the Ediacaran, after the Gaskiers glaciation. Figure 8B scales the divergences to the results of phylogenetic molecular clock studies for the origin of metazoa, cnidarians, and the protostome-deuterostome ancestor. Here, much of metazoan divergence appears closely tied to the Marinoan glaciation, although with the broad uncertainties inherent in molecular clock studies, we can make no claims for any direct relationship to this major paleoecological event. All the divergences shown in Figure 8B occur well before the appearance of these lineages in the currently known fossil record, even assuming the earlier dates for the Doushantuo.

In studying the developmental basis of these major evolutionary events, we cannot rely on looking at small changes. We can, however, look forward to a more direct approach: predictive, experimental alteration of morphology in the developmental gene regulation laboratory.

\section{SUMMARY}

The following are the major conclusions from the arguments and evidence we traversed in this paper:

1. Integration of fossil, phylogenetic, and developmental evidence indicates that "bilaterians" evolved progressively from cnidarians through acoels to the protostomedeuterostome divergence. Consequently, there is not a single node associated with the "origin of the bilateria."

2. A variety of eumetazoan clades were present by the time of the Doushantuo fossil embryos in the Ediacaran Period, including cnidarians and possibly stem group acoels; some also exhibit bilaterian characteristics.

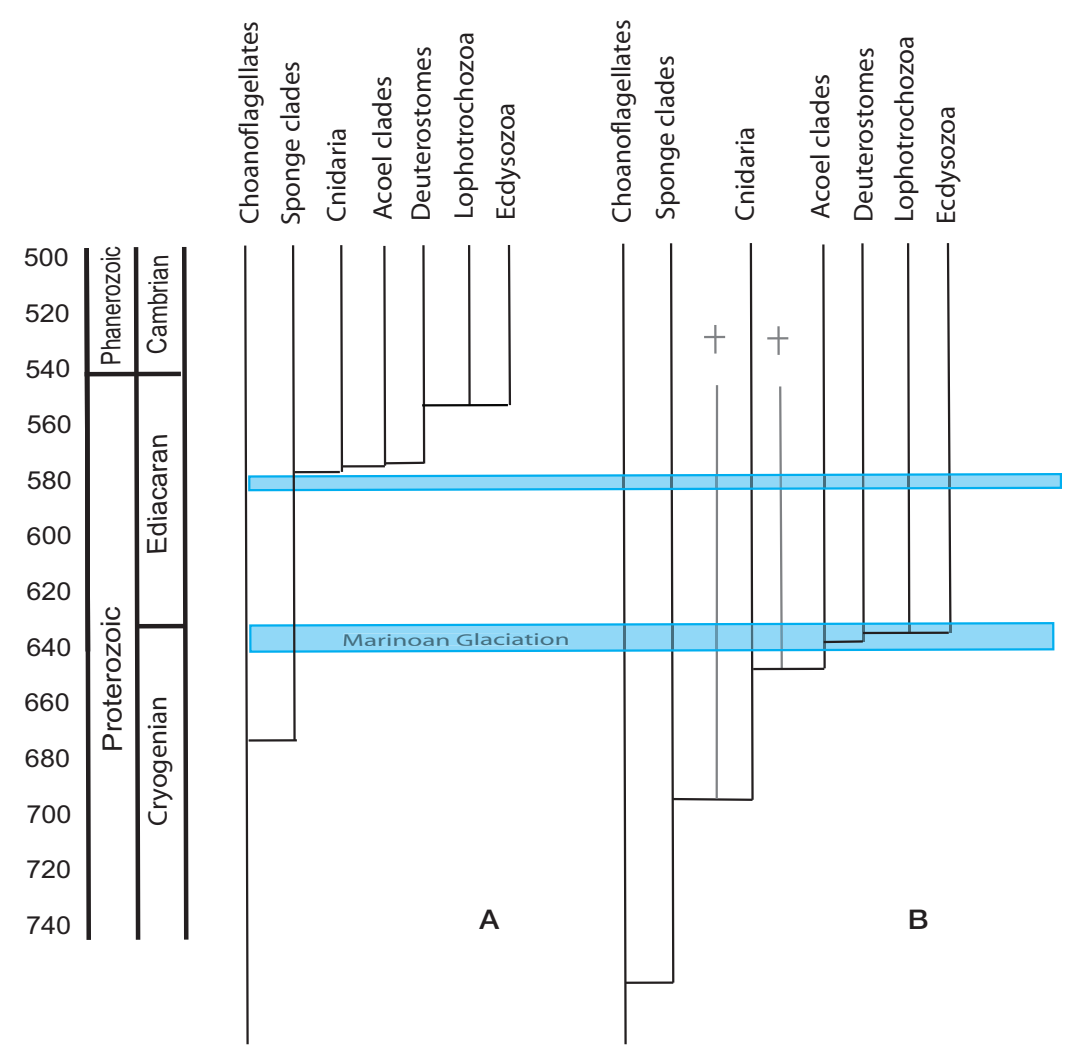

Figure 8. Alternative models for the timing of origination of bilaterian animals. (A) A strict interpretation of the origin of metazoan lineages that is consistent with the fossil record, assuming that sponges appear before the Marinoan glaciation, that the Doushantuo Formation postdates the Gaskiers glaciation, and that Kimberella marks the first appearance of a lophotrochozoan lineage. $(B)$ Timing of the appearances of metazoan lineages in relationship to geological events, with divergences scaled to molecular clock results of Douzery et al. (2004) and Peterson et al. (2008). Uncertainties on the divergence points are not shown, but they are generally 10 million years or more. We have also added extinct lineages (denoted by crosses) representing the possible positions of various clades of the Ediacaran fauna. 
3. Although the soft-bodied Ediacaran fossils of 579-542 mya include a number of independent metazoan clades, only one (Kimberella) clearly lies above the protostome-deuterostome divergence. Some of these clades could represent lineages between the cnidarians and the acoels or Nemertodermatida.

4. Geochemical evidence, the appearance of Kimberella, and the oldest definitive macroscopic eumetazoan traces all occur near 555 mya, consistent with the development of sufficient oxygen levels to sustain large complex animals of eumetazoan grade near this time.

5. The increasing morphologic complexity of eumetazoan lineages likely reflects the number, depth, and subcircuit diversity of the dGRNs required to build the body plan of the animal.

6. From this, it follows that previous stages in metazoan evolution were associated with dGRNs of less complexity, shallower depth, and fewer subcircuits, and with a less hierarchically structured regulatory network.

7. The canalization of developmental processes in eumetazoan lineages is due mechanistically to dGRN hierarchy. This means that the upper-level subcircuits (kernels) will be evolutionarily conserved in all descendants of the lineage. These recursively wired subcircuits provide a developmental explanation for the long-term stability of eumetazoan body plans through the Phanerozoic.

8. Once they had appeared and became responsible for regional patterning in embryonic development, the collective suite of kernels and other upstream dGRN linkages essentially defined the possible "developmental morphospace" of each clade.

9. Linnean taxonomic hierarchy is an imperfect but relevant mirror of the patterning functions established by kernels and other elements of dGRNs in building the body plan.

10. The evolution of dGRNs involves the insertion of additional subcircuit devices through intercalary evolution. Continuation of the process results in expansion of network structure. Some subcircuits are formed that act as switches and are frequently reused in the evolution of development.

11. The downstream processes of morphogenesis are controlled by functional dGRN regulatory linkages through differentiation gene batteries, cell biology, and morphogenetic gene cassettes. These directly deploy morphogenetic cellular functions, and the evolution of morphology has occurred by changes in the circuitry controlling their deployment.

\section{ACKNOWLEDGMENTS}

E.H.D. acknowledges support from National Science Foundation grant IOS-0641398. D.H.E. acknowledges support from NASA's National Astrobiology Institute.

\section{REFERENCES}

Abzhanov A, Kuo WP, Hartmann C, Grant BR, Grant PR, Tabin CJ. 2006. The calmodulin pathway and evolution of elongated beak morphology in Darwin's finches. Nature 442: 563-567.

Amit I, Garber M, Chevrier N, Leite AP, Donner Y, Eixenhaure T, Guttman M, Grenier JK, Li WG, Zuk O, et al. 2009. Unbiased reconstruction of a mammalian transcriptional network mediating pathogen responses. Science 325: 257-263.

Arenas-Mena C, Martinez C, Cameron AR, Davidson EH. 1998. Expression of the Hox gene complex in the indirect development of a sea urchin. Proc Natl Acad Sci 95: 13062-13067.

Arendt D, Wittbrodt J. 2001. Reconstructing the eyes of Urbilateria. Philos Trans R Soc Lond B Biol Sci 356: 1545-1563.

Aris-Brosou S, Yang Z. 2003. Bayesian models of episodic evolution support a late precambrian explosive diversification of the metazoa. Mol Biol Evol 20: 1947-1954.

Baguñà J, Martinez P, Paps J, Riutort M. 2008. Back in time: A new systematic proposal for the Bilateria. Philos Trans R Soc Lond B Biol Sci 363: 1481-1491.

Balavoine G, Adoutte A. 2003. The segmented Urbilateria: A testable scenario. Int Comp Biol 43: 137-147.

Barfod GH, Albarede F, Knoll AH, Xiao SH, Telouk P, Frei R, Baker J. 2002. New Lu-Hf and Pb-Pb age constraints on the earliest animal fossils. Earth Planet Sci Lett 201: 203-212.

Bolouri H, Davidson EH. 2009. The gene regulatory network basis of the "community effect," and analysis of a sea urchin embryo example. Dev Biol (in press).

Butterfield NJ. 2009. Oxygen, animals and oceanic ventilation: An alternative view. Geobiology 7: 1-7.

Canfield DE, Poulton SW, Knoll AH, Narbonne GM, Ross G, Goldberg T, Strauss H. 2008. Ferruginous conditions dominated later Neoproterozoic deep-water chemistry. Science 321: 949 952.

Catling DC, Glein CR, Zahnle KJ, McKay CP. 2005. Why $\mathrm{O}_{2}$ is required by complex life on habitable planets and the concept of planetary “oxygenation time." Astrobiology 5: 415-438.

Chan YF, Marks ME, Jones FC, Villarreal G Jr, Shapiro MD, Brady SD, Southwick AM, Absher DM, Grimwood J, Schmutz J, et al. 2009. Adaptive evolution of pelvic reduction in sticklebacks by recurrent deletion of a Pitx1 enhancer. Science 327: 302-305.

Chen JY, Oliveri P, Li C-W, Zhou G-Q, Gao F, Hagadorn JW, Peterson KJ, Davidson EH. 2000. Precambrian animal diversity: Putative phosphatized embryos from the Doushantuo Formation of China. Proc Natl Acad Sci 97: 4457-4462.

Chen JY, Oliveri P, Gao F, Dornbos SQ, Li CW, Bottjer DJ, Davidson EH. 2002. Precambrian animal life: Probable developmental and adult cnidarian forms from Southwest China. Dev Biol 248: 182-196.

Chen JY, Bottjer DJ, Oliveri P, Dornbos SQ, Gao F, Ruffins S, Chi H, Li CW, Davidson EH. 2004a. Small bilaterian fossils from 40 to 55 million years before the cambrian. Science 305: 218-222.

Chen JY, Oliveri P, Davidson EH, Bottjer DJ. 2004b. Response to comment on "Small bilaterian fossils from 40 to 55 million years before the Cambrian." Science 306: 1291b.

Chen JY, Bottjer DJ, Davidson EH, Dornbos SQ, Gao X, Yang YH, Li C-W, Li G, Wang X-Q, Xian D-C, et al. 2006. Phosphatized polar lobe-forming embryos from the Precambrian of Southwest China. Science 312: 1644-1646.

Chen JY, Bottjer DJ, Davidson EH, Li G, Gao F, Cameron RA, Hadfield MG, Xian DC, Tafforeau P, Jia QJ, et al. 2009a. Phase contrast synchrotron X-ray microtomography of Ediacaran (Doushantuo) metazoan microfossils: Phylogenetic diversity and evolutionary implications. Precambrian Res 173: 191-200.

Chen JY, Bottjer DJ, Li G, Hadfield MG, Gao F, Cameron AR, Zhang CY, Xian DC, Tafforeau P, Liao X, et al. 2009b. Complex embryos displaying bilaterian characters from Precambrian Doushantuo phosphate deposits, Weng'an, Guizhou, China. Proc Natl Acad Sci 106: 19056-19060.

Chen YQ, Jiang SY, Ling HF, Yang JH. 2009c. Pb-Pb dating of black shales from the lower Cambrian and Neoproterozoic strata, South China. Chemie der Erde 69: 183-189.

Christiaen L, Davidson B, Kawashima T, Powell W, Nolla H, 
Vranizan K, Levine M. 2008. The transcription/migration interface in heart precursors of Ciona intestinalis. Science 320: 1349-1352.

Cohen PA, Knoll AH, Kodner RB. 2009. Large spinose microfossils in Ediacaran rocks as resting stages of early animals. Proc Natl Acad Sci 106: 6519-6524.

Condon D, Zhu M, Bowring S, Wang W, Yang A, Jin Y. 2005. U-Pb ages from the Neoproterozoic Doushantuo Formation, China. Science 308: 95-98.

Corsetti FA, Olcott AN, Bakermans C. 2006. The biotic response to Neoproterozoic snowball Earth. Paleaeogeogr Palaeoclimatol Palaeoecol 232: 114-130.

Cretekos CJ, Wang Y, Green ED, Martin JF, Rasweiler JJ IV, Behringer RR. 2008. Regulatory divergence modifies limb length between mammals. Genes Dev. 22: 141-151.

Crowley TJ, Hyde WT, Peltier WR. 2001. $\mathrm{CO}_{2}$ levels required for deglaciation of a "near-snowball" Earth. Geophys Res Lett 28: 283-286.

Davidson EH. 2001. Genomic regulatory systems. Academic, San Diego.

Davidson EH. 2006. The regulatory genome. Academic, San Diego.

Davidson EH. 2009. Network design principles from the sea urchin embryo. Curr Opin Genet Dev 19: 535-540.

Davidson EH, Erwin DH. 2006. Gene regulatory networks and the evolution of animal body plans. Science 311: 796-800.

Davidson EH, Erwin DH. 2009. Evolutionary innovation and stability in animal gene networks. J Exp Zool B Mol Dev Evol 312: (in press).

Dornbos SQ, Bottjer DJ, Chen JY, Gao F, Oliveri P, Li C-W. 2006. Environmental controls on the taphonomy of phosphatized animals and animal embryos from the Neoproterozoic Doushantuo Formation, Southwest China. Palaios 21: 3-14.

Douzery E, Snell E, Bapteste E, Delsuc F, Philippe H. 2004. The timing of eukaryotic evolution: Does a relaxed molecular clock reconcile proteins and fossils? Proc Natl Acad Sci 101: 1538615391.

Dunn EF, Moy VN, Angerer LM, Angerer RC, Morris RL, Peterson KJ. 2007. Molecular paleontology: Using gene regulatory analysis to address the origins of complex life cycles in the late Precambrian. Evol Dev 9: 10-24.

Dunn CW, Hejnol A, Matus DQ, Pang K, Browne WE, Smith SA, Seaver E, Rouse GW, Obst M, Edgecombe GD, et al. 2008 . Broad phylogenomic sampling improves resolution of the animal tree of life. Nature 452: 745-749.

Erwin DH. 2007. Disparity: Morphological pattern and developmental context. Palaeontology 50: 57-73.

Erwin DH. 2008. Macroevolution of ecosystem engineering, niche construction and diversity. Trends Ecol Evol 23: 304-310.

Erwin DH. 2009. Early origin of the bilaterian developmental toolkit. Philos Trans R Soc Lond B Biol Sci 364: 2253-2261.

Erwin DH, Davidson EH. 2009. The evolution of hierarchical gene regulatory networks. Nat Rev Genet 10: 141-148.

Fedonkin MA, Waggoner BM. 1997. The late Precambrian fossil Kimberella is a mollusc-like bilaterian organism. Nature 388: 868

Fedonkin MA, Gehling JG, Grey K, Narbonne GM, Vickers-Rich P. 2007a. The rise of animals. Johns Hopkins University Press, Baltimore.

Fedonkin MA, Simonetta A, Ivantsov AY. 2007b. New data on Kimberella, the Vendian mollusc-like organism (White Sea region, Russia): Paleontological and evolutionary implications. In The rise and fall of the Ediacaran Biota (ed. P Vickers-Rich and P Komarower), pp. 157-179. Geological Society, London.

Fike DA, Grotzinger JP, Pratt LM, Summons RE. 2006. Oxidation of the Ediacaran Ocean. Nature 444: 744-747.

Finnerty JR. 2005. Did internal transport, rather than directed locomotion, favor the evolution of bilateral symmetry in animals? BioEssays 27: 1174-1180.

Finnerty JR, Pang K, Burton P, Paulson D, Martindale MQ. 2004. Origins of bilateral symmetry: Hox and $d p p$ expression in a sea anemone. Science 304: 1335-1337.

Gao F, Davidson EH. 2008. Transfer of a large gene regulatory apparatus to a new developmental address in echinoid evolution. Proc Natl Acad Sci 105: 6091-6096.

Gehling JG, Droser ML, Jensen SR, Runnegar BN. 2005. Ediacara organisms: Relating form to function. In Form and function: Fossils and development (ed. DEG Briggs), pp. 43-66. Peabody Museum of Natural History, Yale University, New Haven, CT.

Gehring WJ, Ikeo K. 1999. Pax 6. Mastering eye morphogenesis and eye evolution. Trends Genet 15: 371-375.

Hagadorn JW, Xiao S, Donoghue PC, Bengtson S, Gostling NJ, Pawlowska M, Raff EC, Raff RA, Turner FR, Chongyu Y, et al. 2006. Cellular and subcellular structure of Neoproterozoic animal embryos. Science 314: 291-294.

Halverson GP, Hoffman PF, Schrag DP, Maloof AC, Rice AHN. 2006. Toward a Neoproterozoic composite carbon isotope record. GSA Bull 117: 1181-1207.

Hejnol A, Martindale MQ. 2008. Acoel development supports a simple planula-like urbilaterian. Philos Trans R Soc Lond B Biol Sci 363: 1493-1501.

Higgins JA, Schrag DP. 2003. Aftermath of a snowball Earth. Geochem Geophys Geosys 4: 1028.

Hinman VF, Nguyen AT, Cameron RA, Davidson EH. 2003. Developmental gene regulatory network architecture across 500 million years of echinoderm evolution. Proc Natl Acad Sci 100: 13356-13361.

Hoffman PF, Schrag DP. 2002. The snowball Earth hypothesis: Testing the limits of global change. Terra Nova 14: 129-155.

Hoffman PF, Kaufman AJ, Halverson GP, Schrag DP. 1998. A Neoproterozoic snowball Earth. Science 281: 1342-1346.

Jensen S, Droser ML, Gehling JG. 2005. Trace fossil preservation and the early evolution of animals. Palaeogeogr Palaeoclimatol Palaeoecol 220: 19-29.

Jensen S, Droser ML, Gehling JG. 2006. A critical look at the Ediacaran trace fossil record. In Neoproterozoic geobiology and paleobiology (ed. S Xiao and AJ Kaufman), pp. 115-157. Springer, Berlin.

Kaufman AJ, Knoll AH, Narbonne GM. 1997. Isotopes, ice ages, and terminal Proterozoic earth history. Proc Natl Acad Sci 94: 6600-6605.

Kimmel CB. 1996. Was Urbilateria segmented? Trends Genet 12: 329-332.

King N, Hittinger CT, Carroll SB. 2003. Evolution of key cell signaling and adhesion protein families predates animal origins. Science 301: 361-363.

King N, Westbrook MJ, Young SL, Kuo A, Abedin M, Chapman J, Fairclough S, Hellsten U, Isogai Y, Letunic I, et al. 2008. The genome of the choanoflagellate Monosiga brevicollis and the origin of metazoans. Nature 451: 783-788.

Koide T, Hayata T, Cho KWY. 2005. Xenopus as a model system to study transcriptional regulatory networks. Proc Natl Acad Sci 102: 4943-4948.

Levine M, Davidson EH. 2005. Gene regulatory networks for development. Proc Natl Acad Sci 102: 4936-4942.

Littlewood DTJ, Smith AB. 1995. A combined morphological and molecular phylogeny for sea urchins. Philos Trans $R$ Soc Lond B Biol Sci 347: 213-234.

Love GD, Grosjean E, Stalvies C, Fike DA, Grotzinger JP, Bradley AS, Kelly AE, Bhatia M, Meredith W, Snape CE, et al. 2009. Fossil steroids record the appearance of Demospongiae during the Cryogenian period. Nature 457: 718-721.

Marshall CR, Valentine JW. 2009. The importance of preadapted genomes in the origin of the animal bodyplans and the Cambrian explosion. Evolution 9999: 999A.

Martin MW, Grazhdankin DV, Bowring SA, Evans DA, Fedonkin MA, Kirschvink JL. 2000. Age of Neoproterozoic bilaterian body and trace fossils, White Sea, Russia: Implications for metazoan evolution. Science 288: 841-845.

Martindale MQ, Hejnol A. 2009. A developmental perspective: Changes in the position of the blastopore during bilaterian evolution. Dev Cell 17: 162-174.

Martindale MQ, Finnerty JR, Henry JQ. 2002. The Radiata and the evolutionary origins of the bilaterian body plan. Mol Phylogenet Evol 24: 358-365.

Martindale MQ, Pang K, Finnerty JR. 2004. Investigating the ori- 
gins of tripoblasty: 'Mesoderma' gene expression in a diploblastic animal, the sea anemone Nematostella vectensis (Phylum, Cnidaria; class Anthozoa). Development 131: 2463-2474.

Matus DQ, Thomsen GH, Martindale MQ. 2007. FGF signaling in gastrulation and neural development in Nematostella vectensis, an anthozoan cnidarian. Dev Genes Evol 217: 137-148.

McCauley BS, Weideman EP, Hinman VF. 2009. A conserved gene regulatory network subcircuit drives different developmental fates in the vegetal pole of highly divergent echinoderm embryos. Dev Biol (in press).

McFadden KA, Huang J, Chu X, Jiang G, Kaufman AJ, Zhou C, Yuan X, Xiao S. 2008. Pulsed oxidation and biological evolution in the Ediacaran Doushantuo Formation. Proc Natl Acad Sci 105: 3197-3202.

Minelli A. 2009. Perspectives in animal phylogeny and evolution. Oxford University Press, Oxford.

Narbonne GM. 2005. The Ediacara biota: Neoproterozoic origin of animals and their ecosystems. Annu Rev Earth Planet Sci 33: 421-442.

Nielsen C. 2008. Six major steps in animal evolution: Are we derived sponge larvae? Evol Dev 10: 241-257.

Oliveri P, Tu Q, Davidson EH. 2008. Global regulatory logic for specification of an embryonic cell lineage. Proc Natl Acad Sci 105: 5955-5962.

Owraghi M, Broitman-Maduro G, Luu T, Roberson H, Maduro MF. 2009. Roles of the Wnt effector POP-1/TCT in the C. elegans endomesoderm specification gene network. Dev Biol (in press).

Paps J, Baguñà J, Ruitort M. 2009. Lophotrochozoa internal phylogeny: New insights from an up-to-date analysis of nuclear ribosomal genes. Proc Biol Sci 276: 1245-1254.

Peter IS, Davidson EH. 2009a. The endoderm gene regulatory network in sea urchin embryos up to the mid-blastula stage. Dev Biol (in press).

Peter IS, Davidson EH. 2009b. Modularity and design principles in the sea urchin embryo gene regulatory network. FEBS Lett 583: 3948-3958.

Peterson KJ, Butterfield NJ. 2005. Origin of the Eumetazoa: Testing ecological predictions of molecular clocks against the Proterozoic fossil record. Proc Natl Acad Sci 102: $9547-$ 9552.

Peterson KJ, Cotton JA, Gehling JG, Pisani D. 2008. The Ediacaran emergence of bilaterians: Congruence between the genetic and the geological fossil records. Philos Trans R Soc Lond B Biol Sci 363: $1435-1443$.

Philippe H, Derelle R, Lopez P, Pick K, Borchiellini C, BouryEsnault N, Vacelet J, Renard E, Houliston E, Queinnec E, et al. 2009. Phylogenomics revives traditional views on deep animal relationships. Curr Biol 19: 706-712.

Putnam NH, Srivastava M, Hellsten U, Dirks B, Chapman J, Salamov A, Terry A, Shapiro H, Lindquist E, Kapitonov VV, et al. 2007. Sea anemone genome reveals ancestral eumetazoan gene repertoire and genomic organization. Science 317: 86-94.

Rebeiz M, Pool JE, Kassner VA, Aquadro CF, Carroll SB. 2009. Stepwise modification of a modular enhancer underlies adaptation in a Drosophila population. Science 326: 1663-1667.

Ruvkun G, Wightman B, Burglin T, Arasu P. 1991. Dominant gain-of-function mutations that lead to misregulation of the $C$. elegans heterochronic gene lin-14, and the evolutionary implications of dominant mutations in pattern-formation genes. Dev Suppl 1: 47-54.
Schierwater B, Eitel M, Jakob W, Osigus HJ, Hadrys H, Dellaporta SL, Kolokotronis SO, Desalle R. 2009. Concatenated analysis sheds light on early metazoan evolution and fuels a modern "urmetazoon" hypothesis. PLoS Biol 7: e20.

Scott C, Lyons TW, Bekker A, Shen Y, Poulton SW, Chu X, Anbar AD. 2008. Tracing the stepwise oxygenation of the Proterozoic ocean. Nature 452: 456-459.

Shen Y, Zhang TG, Hoffman PF. 2008. On the coevolution of Ediacaran oceans and animals. Proc Natl Acad Sci 105: 7376-7381.

Smith J, Davidson EH. 2009. Regulative recovery in the sea urchin embryo and the stabilizing role of fail-safe gene network wiring. Proc Natl Acad Sci 106: 18291-18296.

Sperling EA, Pisani D, Peterson KJ. 2007. Poriferan paraphyly and its implications for Precambrian palaeobiology. In The rise and fall of the Ediacaran biota (ed. P Vickers-Rich and $\mathrm{P}$ Komarower), pp. 355-368. Geological Society, London.

Sperling EA, Peterson KJ, Pisani D. 2009a. Phylogenetic-signal dissection of nuclear housekeeping genes supports the paraphyly of sponges and the monophyly of Eumetazoa. Mol Biol Evol 26: 2261-2274.

Sperling EA, Robinson JM, Pisani D, Peterson KJ. 2009b. Where is the glass? Biomarkers, molecular clocks, and microRNAs suggest a 200-Myr missing Precambrian fossil record of siliceous sponge spicules. Geobiology 8: 24-36.

Srivastava M, Begovic E, Chapman J, Putnam NH, Hellsten U, Kawashima T, Kuo A, Mitros T, Salamov A, Carpenter ML, et al. 2008. The Trichoplax genome and the nature of placozoans. Nature 454: 955-960.

Stathopoulos A, Levine M. 2005. Genomic regulatory networks and animal development. Dev Cell 9: 449-462.

Technau U. 2001. Brachyury, the blastopore and the evolution of the mesoderm. BioEssays 23: 788-794.

Technau U, Rudd S, Maxwell P, Gordon PM, Saina M, Grasso LC, Hayward DC, Sensen CW, Saint R, Holstein TW, et al. 2005. Maintenance of ancestral complexity and non-metazoan genes in two basal cnidarians. Trends Genet 21: 633-639.

Thompson MD, Bowring SA. 2000. Age of the Squantum "tillite" Boston Basin, Massachusetts: U-Pb zirco constraints on terminal Neoproterozoic glaciation. Am J Sci 300: 630-655.

Towe KM. 1970. Oxygen-collagen priority and the early metazoan fossil record. Proc Natl Acad Sci 65: 781-788.

Wallberg A, Curini-Galletti M, Ahmadzadeh A, Jondelius U. 2007. Dismissal of Acoelomorpha: Acoela and Nemertodermatida are separate early bilaterian clades. Zool Scripta 36: 509-523.

Xiao SH. 2002. Mitotic topologies and mechanics of Neoproterozoic algae and animal embryos. Paleobiology 28: 244-250.

Xiao SH, Knoll AH. 1999. Fossil preservation in the Neoproterozoic Douchantuo phosphorite Lagerstatte, South China. Lethaia 32: $219-240$.

Xiao SH, Knoll AH. 2000. Phosphatized animal embryos from the Neoproterozoic Doushantuo Formation at Weng'an, Guizhou, South China. J Paleontol 74: 767-788.

Xiao SH, Laflamme M. 2008. On the eve of animal radiation: Phylogeny, ecology and evolution of the Ediacara biota. Trends Ecol Evol 24: 31-40.

Yin L, Zhu M, Knoll AH, Yuan X, Zhang J, Hu J. 2007. Doushantuo embryos preserved inside diapause egg cysts. Nature 446: 661-663.

Yuh CH, Bolouri H, Davidson EH. 2001. Cis-regulatory logic in the endo16 gene: Switching from a specification to a differentiation mode of control. Development 128: 617-629. 


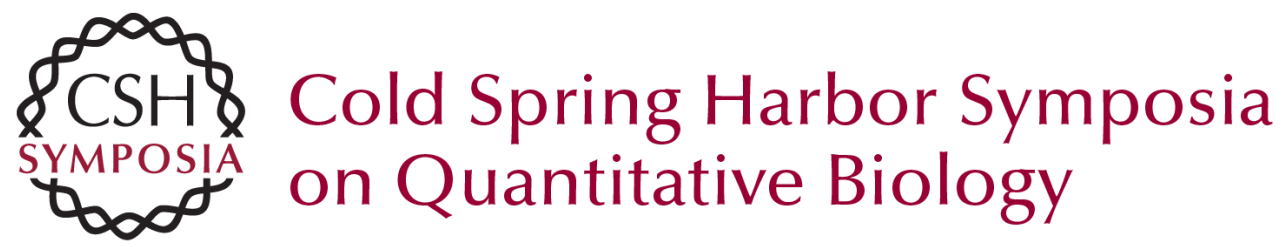

\title{
An Integrated View of Precambrian Eumetazoan Evolution
}

\author{
E.H. Davidson and D.H. Erwin
}

Cold Spring Harb Symp Quant Biol 2009 74: 65-80 originally published online April 7, 2010 Access the most recent version at doi:10.1101/sqb.2009.74.042

References This article cites 95 articles, 37 of which can be accessed free at: http://symposium.cshlp.org/content/74/65.full.html\#ref-list-1

License

Email Alerting Receive free email alerts when new articles cite this article - sign up in the box at the Service top right corner of the article or click here.

To subscribe to Cold Spring Harbor Symposia on Quantitative Biology go to: http://symposium.cshlp.org/subscriptions 